\title{
Is corporate social responsibility sufficient enough to explain the investment by socially responsible funds?
}

\author{
Onur Kemal Tosun ${ }^{1}$
}

Published online: 18 October 2016

(C) The Author(s) 2016. This article is published with open access at Springerlink.com

\begin{abstract}
I propose an explanation for investment decisions by socially responsible investment funds (SRI) on the firms with higher corporate social responsibility (CSR). Different from the previous literature, I use a unique and comprehensive measure that considers both firm CSR ratings and fund CSR perception. I show SRI mutual funds increase their ownership about $15 \%$ for one unit increase in the firm CSR score when those funds are highly sensitive to CSR. This finding is more pronounced for employee relations and society areas of CSR. The results also hold for a broader range of mutual funds. While industry concentration does not have influence on the fund investment, SRI funds particularly choose socially responsible firms operating in construction, transportation, personal services, and financial sector. I show the funds with CSR sensitivity underperform the market in general and fail to improve their portfolio performance after they invest in the firms with high CSR.
\end{abstract}

Keywords Socially responsible investment - Corporate social responsibility · Employee relations · Dual measure · Portfolio performance

JEL Classification G30 - G11 · M14 · C33

Electronic supplementary material The online version of this article (doi:10.1007/s11156-016-0605-x) contains supplementary material, which is available to authorized users.

Onur Kemal Tosun

Onur.Tosun@wbs.ac.uk

1 Warwick Business School, University of Warwick, Coventry, UK 


\section{Introduction and related literature}

Corporate social responsibility (CSR) refers to a business practice that involves firm commitment to contribute to social benefits in the aspect of the quality of life of community and society. Especially in the last decade, companies started to invest in practices to improve social responsibility. Haagen-Dazs created a microsite to raise awareness about disappearing honeybees that are essential for the global food chain. The firm is donating a portion of proceeds from its Haagen-Dazs honeybee brand to research on the topic. Starbucks has created its practice guidelines named Coffee and Farmer Equity (C.A.F.E.), which is a comprehensive coffee-buying program that ensures coffee quality while promoting social, economic, and environmental standards. The company also promotes products, such as Ethos Water, which brings clean water to over 1 billion people without water access. For each pair sold, Juntos Shoes, an ethically conscious fashion start-up company, donates a school supply-filled backpack to an at-risk Ecuadorean child.

Meanwhile, the socially responsible mutual funds shift their attention more towards the firms with high CSR. These SRI funds aim to attract the investors with high awareness of social issues who also seek high returns on their investments. According to the Social Investment Forum report (2014), more than $16 \%$ of the assets under professional management in the United States are in SRI funds. In particular, SRI funds expanded their portfolios about $76 \%$ from $\$ 3.74$ trillion (2012) to $\$ 6.57$ trillion (2014).

Many prior studies focus on the relation between SRI investments and firm CSR, and document potential determinants of this link. From the firm's point of view; Ghoul et al. (2011), and Albuquerque et al. (2014) argue that the highly socially responsible firms often have lower systematic risk, and hence can have access to cheaper capital by SRI. Cheng et al. (2014) suggest that CSR reduces informational asymmetry and agency cost in firms via increased transparency that may provide less capital constraints by the socially responsible funds. Benabou and Tirole (2010) find that CSR policies give firms a long-term focus via helping them to avoid short-termism and strengthening their market position. This potential firm value increasing effect leads SRI funds to invest in the firms with high CSR values. From the investors' perspective; Williams (2007), Portne (2008), and Karakas et al. (2015) argue that fund managers with concerns about the social issues prefer to invest in the firms with CSR practices. Karakas et al. (2015) also find that institutional investors increase their ownership in the companies adopting CSR changes. Buzby and Falk (1978), and Berry and Junkus (2013) suggest each SRI fund uses specific CSR screening criteria while deciding on its investment in the firms with CSR policies. Hong and Kostovetsky (2012), and Giuli and Kostovetsky (2014) consider the political view of fund managers and highly socially responsible companies. They find firms with Democratic views have higher CSR and mostly, they are linked to funds with managers sharing the similar political view.

The existing studies make important contributions, but so far, the previous literature considers mainly the firm's social responsibility to establish the link between SRI funds and the firms' CSR practices. Using only the firm CSR perspective but discarding the SRI funds' CSR perception can only partially explain the investment by those mutual funds in socially conscious firms. Thus, the main research question in this paper is "Is firms' CSR sufficient enough to explain the investment by SRI mutual funds?" Although it is known that SRI funds may have different CSR perceptions, it is surprising that previous studies leave out this key component from the analysis. This may indeed explain some of the inconclusive findings in literature, and hence, it is important to explore funds' view on CSR. 
In this study, I expand the existing approach by also ruminating the mutual funds' CSR perspective. Each SRI fund has a different perception of CSR and hence, reacts differently to firms' CSR activities. Some mutual funds may decrease their ownership in less socially responsive firms, but an improvement in firms' CSR may not affect these funds because they might be more focused on the downside of the CSR applications. In contrast, other funds may concentrate only on the CSR improvements in companies and invest in the firms with better CSR while they don't react to the poor CSR practices. Consequently, changes in firm CSR may not influence each SRI mutual fund the same way. Therefore, the relationship between the socially responsible investment and firms' CSR can only be fully explained via examining both factors: firm CSR values and how sensitive SRI mutual funds towards the CSR practices.

As discussed in Renneboog et al. (2008), SRI funds apply different generations of screens to pick stocks. They use negative and positive filters regarding different CSR criteria. However, the screening process doesn't explain how (whether) SRI funds are committed to those CSR criteria. Even though those mutual funds use filtering on stocks, they may not necessarily invest in all the firms passed the screening. There might be a final stage of decision making for their investment. It might be explained via their commitment to CSR and how sensitive they are about the issues in CSR. Regarding how strong their commitment is, SRI funds may invest in all or a portion of the selected stocks. So, examining their sensitivity towards the CSR activities in firms may reveal that missing piece in those funds' investment process. Hence, it is important to consider funds' CSR sensitivity while investigating the relation between SRI and firm CSR changes. This can provide a complete understanding about how SRI funds select firms and which of those stocks they invest in.

Different from the literature, I introduce a unique new measure that combines the CSR score of each company with the CSR sensitivity of each SRI mutual fund investing in that firm. Firm CSR score incorporates "Strengths" and "Concerns" of each "Kinder, Lydenberg, and Domini Index" (KLD) issue area. Fund CSR Sensitivity is evaluated by SRI funds' investment policy data for negative (restricted) investment and positive investment which are available from Bloomberg's Environmental, Social and Governance (ESG) Service. For this new measure, I match each specific KLD issue area (All, Employee, Society, Governance, and Environment) with the relevant Fund CSR Sensitivity group. By doing so, I can describe the responsiveness of SRI mutual funds to the changes in firms' CSR scores accurately. Moreover, I construct an alternative sensitivity measure to reach a broader spectrum of mutual funds. Using the holding data, I run a time series regression of changes in portfolio weights on changes in firm CSR. I repeat this analysis for each specific area of CSR. As a result, each firm's coefficient estimate is the fund's sensitivity to CSR.

I find a significant increase in the investment by SRI mutual funds in the given firms, both when those firms increase their CSR scores and when the funds have strong sensitivity towards CSR. Contrary to Gillan et al. (2010), and Giuli and Kostovetsky (2014) but consistent with Karakas et al. (2015), my findings show SRI mutual funds are indeed reactive to the firms' effort to improve CSR. Repeating the same analysis with firm CSR scores alone, as in the previous literature, provides weak results. This indicates firms' CSR by itself is not sufficient enough to explain the investment by SRI funds.

In literature, the causal relation between SRI and CSR is carefully studied with natural shocks or instrumental variable approaches. ${ }^{1}$ Different from the literature, I use "new fund

1 Albuquerque et al. (2014) instrument CSR using data on the political affiliation of companies, environ-
mental and engineering disasters, and product recalls in order to address the endogeneity problem. Giuli and 
emergence" in my analysis to address the reverse causality issue. Since firms cannot anticipate non-existing SRI funds and their investments, any CSR practices by firms couldn't have been done to attract those new funds. Hence, the new funds' initial investment decision cannot influence firms' CSR score. But the new SRI mutual funds engage with firms based on their CSR scores when those funds trade the first time in the market. Therefore, the only possible causal effect is by the firm CSR on the new mutual funds' investment decision.

A survey of 1122 global corporations regarding benefits of CSR conducted by the Economist (2008) particularly illustrates an interesting aspect: $37.5 \%$ of the corporate executive respondents point out "the increased attractiveness to potential and existing employees" as one of the main benefits of having CSR practices. ${ }^{2}$ In this paper, I further examine the specific CSR areas in which SRI funds may have a special interest. Similarly, I show evidence that SRI funds are more likely to focus on the human-related issues, such as employee relations and society, in their investment decision.

Benson et al. (2006) investigate the industry effect on the SRI portfolio allocation. They suggest SRI funds invest differently across industry sectors. Following that study, I conduct further analyses on different industries using the new measure. I find the industry concentration (competitiveness) does not have an influence on SRI mutual funds' decisions. Contrary to that, the results are more pronounced for industries, such as construction, transportation, personal services, and financial sector. This finding provides important evidence about the industry preferences of SRI mutual funds while engaging investment decisions.

Sparkes and Cowton (2004) discuss the potential influence of SRI funds on firms to improve CSR. After socially conscious mutual funds invest in companies, they can put pressure on those firms to engage in better CSR practices. I examine this relationship further and find a significant improvement of the firm's CSR score subsequent to such ownership increase by SRI mutual funds. Moreover, this effect is stronger when those funds have high CSR sensitivity. This finding implies that SRI funds may provide society an externality of improving CSR.

Many prior studies attempt to determine the performance of SRI funds. Mallin et al. (1995), Goldreyer and Diltz (1999), Statman (2000), Geczy et al. (2005), Schroder (2007), Chung et al. (2012), Rahman et al. (2016) do not find a statistically significant difference between SRI and non-SRI Fund (Index) performance. Similarly, Nelling and Webb (2009) show that CSR practices in firms do not influence financial performance; hence, SRI funds holding the shares of these firms in their portfolios may not outperform the conventional funds. Using a new multi-level matching method, Wu et al. (2016) demonstrate that CSR has a strongly positive influence on financial performance. Moon and Tosun (2016) show that firms with good CSR practices via better employee relations improve their performance when SRI funds with a similar CSR focus invest in those companies. Subsequently, those SRI mutual funds may have high returns. Further, Derwall and Koedijk (2009), and

Footnote 1 continued

Kostovetsky (2014) use firms' political affiliation along with the CEO, independent board, and non-CEO founders' information to overcome the endogeneity problem while explaining firm CSR.

2 The survey question was to select up to three statements for the main business benefits of CSR. Other benefits that respondents of the survey enumerated include brand reputation (52.9\%), long-term business agenda $(42.4 \%)$, meeting requirement by potential and existing customers $(35.6 \%)$, better relationships with regulators $(27.7 \%)$, higher revenue $(6.5 \%)$, lower costs $(5.9 \%)$, others $(6 \%)$, and not applicable as no CRS (13\%). 
Yu (2014) suggest socially responsible funds have indeed overall high performance. Filbeck et al. (2013) find that portfolios contracted of socially responsible firms ranked highly by popular surveys have high performance. Examining international SRI funds, Bauer et al. (2005) show UK Domestic and International ethical funds demonstrate high returns while US Domestic ethical funds have low performance. Renneboog et al. (2008) find the performance of SRI funds low in most countries except France, Japan and Sweden. In this paper, I further analyze the performance of SRI mutual funds via their portfolios of stocks in which they either increase or decrease their ownership. I conduct the analysis for the whole sample and also for each year individually. Further, I examine their portfolio performance for the different levels of Fund CSR Sensitivity. I also compare the results with the returns of the mutual fund market and NASDAQ. I find that SRI mutual funds fail to improve the performance of their investment portfolios.

This paper makes several contributions. First, it introduces a unique measure which combines Fund CSR Sensitivity with firm CSR ratings. It also uses "new fund emergence" as a new instrument in the analysis. Now, researchers may accurately identify the link between the socially responsible investment and firms' CSR practices. Second, this study provides new evidence for the impact of particular CSR practices, such as employee relations, society, environment, and governance on fund ownership. Lastly, building on the growing literature, it illustrates whether SRI mutual funds can achieve high performance with their specific investment decision. Hence, my results may be useful for ethically conscious funds seeking high returns on their future investments.

This study can be extended in several ways. Further implications of increased SRI ownership, such as its impact on those firms' performance, can be examined. This study has a time period of 10 years. Further research can survey a longer time span. While I focus only on SRI mutual funds in this paper, future studies may consider matching SRI with non-SRI funds to research overall return on investment. Furthermore, this paper investigates the socially responsible funds in the US alone. Examining funds in other countries may bring new insight. The external validity of my results can be tested under these different settings.

The remainder of the paper proceeds as follows. In Sect. 2, I describe the data selection and the variables. Section 3 presents the initial findings. Section 4 explains the empirical methods used to examine socially responsible mutual funds' investment and the performance of their portfolios. Section 5 provides the main results along with the further analyses. In Sect. 6, I present the conclusion.

\section{Data selection and variable construction}

\subsection{Corporate social responsibility (CSR) variables}

The firm CSR data come from Kinder, Lydenberg and Domini (KLD) database. The time span for this study is between 2003 and 2012 because prior to 2003 the coverage of the KLD database is insufficiently small. KLD classify their scores into seven major issue areas (Community, Corporate Governance, Diversity, Employee Relations, Environment, Human Rights, and Product) and six special issue areas (Alcohol, Firearms, Gambling, Military, Nuclear Power, Tobacco) to rate companies' corporate social responsibility. Each major area has several sub-criteria. They represent either a CSR Strength or a CSR 
Concern for which each firm is given one point if the company fits the criterion, and zero otherwise. In total, there are 56 Strength and 59 Concern criteria in KLD.

In this study, I focus on five groups of KLD areas. First, I consider all issue areas together and form a group, "All KLD". ${ }^{3}$ I also have "All KLD (neg)" and "All KLD (pos)" which represent the total accumulated points for only CSR Concern and only CSR Strength, respectively. All KLD is the difference between All KLD (pos) and All KLD (neg). The remaining groups are calculated similarly. "Employee KLD” focuses only on human related aspects in work environment and combines Employee Relations with Human Rights areas of KLD. "Society KLD” is another group as a combination of four major issue areas in KLD: Community, Diversity, Employee Relations, and Human Rights. Society KLD considers CSR in a broader concept than just human relations in work, and includes other social elements of CSR, such as firm relations with communities and firms' view on diversity. "Governance KLD" considers Corporate Governance area of KLD. "Environment KLD" is the last group and contains Environment area of KLD. In the analyses, I use the changes in these measures over time. " $\Delta$ All KLD" is the difference between the current year and the prior year values of All KLD. Similarly, I construct " $\Delta$ All KLD (pos), $\Delta$ All KLD (neg), $\Delta$ Employee KLD, $\Delta$ Society KLD, $\Delta$ Governance KLD and $\Delta$ Environment KLD". The unique predictor variables in my analyses include both mutual funds' CSR sensitivity and firms' KLD score changes. I multiply the " $\Delta$ KLD" variables by the matching "Fund CSR Sensitivity" ratio to construct this fund-adjusted firm KLD measure. This adjustment is necessary because SRI mutual funds may not have the same sensitivity towards each different aspect of CSR; and that may impact their investment decision.

\subsection{Socially responsible investment (SRI) fund variables}

I obtain SRI mutual fund data from the US SIF (The Forum for Sustainable and Responsible Investment) website ${ }^{4}$ because it has the fund data which includes necessary information to construct the Fund CSR Sensitivity measure. The US SIF website provides a chart which displays all SRI mutual funds offered by the US SIF's institutional member firms. The data in the chart are originally provided by the Bloomberg's Environmental, Social and Governance (ESG) Service. It lists all 146 SRI mutual funds and their screening and advocacy criteria for investment. As a member of US SIF, each SRI mutual fund is expected to be evaluated by those criteria. The survey is updated annually (currently as of December, 2015), and it is meant to be backward looking. That is useful as I examine the funds' investment decisions up to 2012.

I merge the sample of 146 SRI mutual funds from US SIF to the Thomson Reuters' S12 holding data, and obtain 47 unique funds. During the matching process, many out of the 146 SRI mutual funds were redundant in terms of fund names. For example, "Calvert Balanced Portfolio A, C, I class shares" in the SRI mutual fund list are all matched to "Calvert Balanced Fund" in S12 holding data. This redundancy in the SRI fund list reduces the number of funds in my sample. I also miss 20 funds in the SRI fund list because those funds newly emerged after the year 2012 which is beyond my sample period.

\footnotetext{
${ }^{3}$ In the corporate social responsibility literature, the companies associated with the six special KLD issue areas are referred as "the sin stocks". These areas are Alcohol, Firearms, Gambling, Military, Nuclear Power, and Tobacco. In this study, I also define "All KLD (sinless)" which is a group focusing on all issue areas excluding "the sin criteria". I obtain robust results.

4 The website is available at http://charts.ussif.org/mfpc/.
} 
After the matching process, I obtain 47 uniquely identified SRI mutual funds. Then, I merge those funds to the fund returns data in CRSP and finally have 32 SRI mutual funds. ${ }^{5}$

The main dependent variable is " \% Change in Ownership". It is the percentage difference in a fund's ownership (measured by shares) as a fraction of the firm. The percentage difference is between the current and the prior year. For the funds' portfolio performance analysis, I calculate the dependent variable "Portfolio Return". It is the weighted average of annual stock returns of firms in the portfolio. Each stock return in the portfolio is weighted by the fund's ownership percentage in that stock. The independent variable is "Invested". It is a dummy variable that equals one if the portfolio contains firms only with increased ownership of one specific fund, and zero otherwise.

Regarding fund control variables, I consider "Fund Return" and "Fund Size". Fund Return is the annual average of the fund's monthly return. Monthly return is calculated via dividing the difference in net asset value of the fund between the current month and the prior month, by the net asset value of the prior month. Fund Size is the annual average of a fund's monthly total net asset value in million dollars. For the portfolio performance tests, I control for the risk via "Portfolio Beta". It is the weighted average of stock betas in each portfolio. The betas are calculated using the market model. Each stock beta in the portfolio is weighted by the fund's ownership percentage in that stock. Furthermore, there might be other non-financial motivations faced by SRI funds, such as shareholder activism, through which SRI funds make CSR a priority over financial returns. These factors may impact portfolio returns. Hence, I control for "Fund Activism" which is the total number of activism proposals by SRI Funds in the board meetings per firm per year.

Bloomberg's Environmental, Social and Governance (ESG) Service data provide a detailed classification of SRI mutual funds based on their reaction to the specific CSR level changes in firms. Each fund manager is contacted to fill out a survey including 17 detailed criteria of CSR under Environment, Governance, Social, and Shareholder Engagement and Others. Regarding those detailed CSR statements, they need to disclose how committed they are to the CSR practices while investing in a firm, and also their attitude towards firms engaging in positive (negative) CSR actions. The possible reactions by funds are "Positive Investment" (the fund invests in a firm if the firm has good CSR practices in that particular criterion, but it doesn't react to the firm's poor practices), "Restricted Investment" (the fund withdraws the investment from a firm if the firm has poor CSR practices in that particular criterion, but it doesn't react to the firm's good practices), and "Full Investment" (the fund invests in a firm if the firm has good CSR practices, and withdraws the investment from the firm, otherwise). This survey is updated annually and it reflects the reaction of each individual fund in different CSR cases. Using those 17 Bloomberg's ESG criteria, I construct "Fund CSR Sensitivity" groups matching to the firm KLD groups: All, Employee, Society, Governance and Environment. I assign points to the funds' different attitudes. A fund earns one point for either of the first two types of reaction, or two points for Full Investment in regards to each of 17 criteria. Lastly, for each fund, the total points earned for a CSR Sensitivity group are normalized by the maximum possible points for that group. This method produces the following Fund CSR Sensitivity ratios: "All Sensitivity, Employee Sensitivity, Society Sensitivity, Environment Sensitivity, and Governance Sensitivity". These sensitivity ratios are unique for each SRI mutual fund, and they do not

\footnotetext{
${ }^{5}$ Using a different measure for Fund CSR Sensitivity, I can focus on a broader range of mutual funds in Thomson Reuters' S12 holding dataset for the additional analyses. I discuss the details and my findings in Further Analyses section of this paper.
} 
change over time. They show the level of commitment of those funds to the specific CSR areas, and have values between 0 and $100 \%$.

An alternative method to construct CSR sensitivity would be to regress the change in fund ownership on the change in firms' CSR scores. I follow this approach for further robustness checks and discuss the findings in Sect. 5.2.2. However, I believe the sensitivity measure constructed via Bloomberg's ESG survey data has advantages over the regression method. Firstly, Fund CSR Sensitivity relies on the data directly gathered from the source of investment, e.g. the fund managers. Hence, it should reflect the SRI funds' CSR perception very accurately. Also, Bloomberg is a highly reliable data provider which should minimize any potential mistakes in construction of the sensitivity measure. Further, Bloomberg has an extensive coverage of SRI mutual funds, which is essential for this study. Lastly, this measure is free from any potential modelling bias since it relies on a simple ratio using survey data. On the contrary, the regression method might produce a sensitivity measure that might lead to a mechanical relation between funds' holding change and CSR change for high-CSR-sensitivity funds.

\subsection{Firm control variables}

I collect the data sample for the firm control variables from COMPUSTAT and CRSP databases. In the analyses, I use 1 year lagged value ${ }^{6}$ of the following control variables: "Profitability" is the ratio of earnings before interest and taxes (EBIT) over total assets; "Firm Size" is the natural logarithm of total assets; "M/B" is the Market-to-Book ratio, calculated via (Common shares outstanding * closing price)/total assets; "Leverage" is the ratio of the sum of debt in current liabilities and long-term debt over total assets; "Volatility" is the standard deviation of monthly stock returns; "Growth" is the ratio of capital expenditures over sales; "Cash" is the net cash holdings over total assets; "R\&D" is the ratio of research and development expenses over sales; "Dividend" is calculated via dividend payments/(Common shares outstanding * closing price); "HHI" is the Herfindahl measure for industry concentration that is computed via the Text-based Network Industry Classification method as suggested by Hoberg and Phillips (2010).

\subsection{Final sample and summary statistics}

The final data sample expands from 2003 to 2012 and contains 32 SRI mutual funds, 1585 firms, and 11,960 firm-fund-year observations. First, I construct "Firm Sample" with the measures for different KLD groups and the firm control variables. Then, I create "Fund Sample" with the SRI mutual funds and the fund controls. Then, I build "Sensitivity Sample" with the Fund CSR Sensitivity ratios. I merge Sensitivity Sample to Fund Sample, and lastly, Firm Sample to that combined fund sample. I require the final complete sample has values for each firm-fund-year observation. In the final sample, each firm should have investment by at least one fund, and positive values for total assets and capital expenditures. Total assets must have a greater value than capital expenditures and total cash holdings. Further, I drop the observations where the sum of long-term and short-term debt is greater than total assets. I winsorize the variables with extreme values at 1 and $99 \%$ to mitigate the effect of outliers.

\footnotetext{
${ }^{6}$ We also use the difference between the current year and the prior year values of the control variables in the analyses. We obtain similar results.
} 
Table 1 Summary statistics

\begin{tabular}{|c|c|c|c|c|c|}
\hline & Mean & $\mathrm{SD}$ & Min & Median & Max \\
\hline \multicolumn{6}{|l|}{ Panel A: Firm characteristics } \\
\hline Total assets (\$ Million) & $23,587.412$ & $39,731.547$ & 45.869 & 6734.409 & $157,818.010$ \\
\hline Firm size & 8.921 & 1.568 & 3.826 & 8.815 & 11.969 \\
\hline $\mathrm{M} / \mathrm{B}$ & 1.468 & 1.293 & 0.050 & 1.127 & 7.491 \\
\hline Profitability & 0.105 & 0.088 & -0.550 & 0.098 & 0.368 \\
\hline Leverage & 0.208 & 0.171 & 0.000 & 0.186 & 0.849 \\
\hline Volatility & 8.391 & 4.474 & 2.903 & 7.430 & 37.649 \\
\hline Growth & 0.076 & 0.167 & 0.000 & 0.033 & 1.394 \\
\hline Dividend & 0.015 & 0.018 & 0.000 & 0.010 & 0.141 \\
\hline Cash & 0.154 & 0.159 & 0.001 & 0.096 & 0.894 \\
\hline $\mathrm{R} \& \mathrm{D}$ & 0.048 & 0.182 & 0.000 & 0.000 & 3.585 \\
\hline HHI & 0.135 & 0.165 & 0.016 & 0.073 & 1.000 \\
\hline \multicolumn{6}{|c|}{ Panel B: SRI fund characteristics } \\
\hline$\%$ Change in ownership & 0.431 & 1.583 & -0.805 & 0.105 & 12.505 \\
\hline Portfolio return & 0.143 & 1.643 & -8.690 & 0.015 & 7.782 \\
\hline Invested & 0.513 & 0.501 & 0 & 1 & 1 \\
\hline Portfolio beta & 0.889 & 0.200 & 0.435 & 0.876 & 1.538 \\
\hline Fund activism & 0.959 & 1.231 & 0 & 1 & 7 \\
\hline Fund return & 0.003 & 0.019 & -0.040 & 0.007 & 0.027 \\
\hline Fund size & 278.381 & 456.705 & 2.388 & 58.783 & 2349.783 \\
\hline All sensitivity & 0.697 & 0.184 & 0.176 & 0.794 & 0.853 \\
\hline Environment sensitivity & 0.452 & 0.138 & 0.167 & 0.500 & 1.000 \\
\hline Employee sensitivity & 0.433 & 0.131 & 0.000 & 0.500 & 0.500 \\
\hline Society sensitivity & 0.361 & 0.101 & 0.000 & 0.417 & 0.417 \\
\hline Governance sensitivity & 0.247 & 0.142 & 0.000 & 0.333 & 0.333 \\
\hline \multicolumn{6}{|c|}{ Panel C: Firm CSR characteristics } \\
\hline All KLD & 1.076 & 3.638 & -10 & 0 & 19 \\
\hline All KLD (pos) & 3.545 & 3.982 & 0 & 2 & 22 \\
\hline All KLD (neg) & 2.470 & 2.085 & 0 & 2 & 16 \\
\hline Environment KLD & 0.365 & 1.046 & -4 & 0 & 5 \\
\hline Employee KLD & -0.251 & 1.465 & -6 & 0 & 8 \\
\hline Society KLD & 1.063 & 2.802 & -8 & 0 & 15 \\
\hline Governance KLD & -0.458 & 0.806 & -4 & -1 & 2 \\
\hline$\Delta$ All KLD & 0.293 & 2.053 & -13 & 0 & 14 \\
\hline$\Delta$ All KLD (pos) & 0.288 & 1.657 & -11 & 0 & 10 \\
\hline$\Delta$ All KLD (neg) & -0.005 & 1.238 & -8 & 0 & 10 \\
\hline$\Delta$ Environment KLD & 0.107 & 0.764 & -4 & 0 & 6 \\
\hline$\Delta$ Employee KLD & 0.157 & 1.089 & -5 & 0 & 8 \\
\hline$\Delta$ Society KLD & 0.190 & 1.513 & -8 & 0 & 10 \\
\hline$\Delta$ Governance KLD & 0.042 & 0.758 & -4 & 0 & 3 \\
\hline
\end{tabular}

This table provides descriptive statistics for the main variables (see Appendix for definitions). I construct cross-sectional summary statistics and then take time-series averages of each statistics across 10 years of our study (2003-2012). There are 32 SRI mutual funds, 1585 firms, and 11,960 firm-fund-year observations in this study. Panel A presents statistics on firm characteristics. Panel B gives statistics on SRI mutual fund while Panel C shows firm CSR characteristics 
Table 1 presents summary statistics on all variables in this study. Panel A includes the variables for firm characteristics. These statistics are in line with prior studies. On average, the firm size is about \$24 Billion due to several large companies in the sample. The mean leverage is $21 \%$. The profitability is $10.5 \%$ while $\mathrm{M} / \mathrm{B}$ is 1.5 , and the growth is $7.6 \%$. Companies' cash holdings are about $15.4 \%$ of their total assets. While firms pay about $1.5 \%$ of their market value as dividend, investment in R\&D is about $5 \%$ of their total sales. The stock return volatility for firms is about 8.4 on average. With the mean Herfindahl (HHI) value of 0.135 , firms in the sample operate in fairly competitive industries.

Panel B, Table 1 focuses on SRI mutual fund characteristics. On average, SRI funds increase their ownership in the socially responsible firms about $43 \%$ within 10 year period in this study. The distribution of this variable is skewed to the right due to some large SRI mutual funds in the sample. Fund Size has a right skewed distribution with an average of $\$ 278.4$ Million. SRI funds have an annual average return of $0.30 \%$. The mean return of their portfolios is $0.14 \%$. The average portfolio beta is about 0.89 . On average, firms have 1 activism proposal by SRI Funds in the board meetings per year. Funds are about $70 \%$ sensitive to the changes in firms' overall CSR. More specifically, CSR Fund Sensitivity is $45,43,36$, and $25 \%$ for environment, employee, society, and governance related CSR changes, respectively.

Panel C of Table 1 displays statistics on firms' CSR characteristics. On average, firms have positive KLD scores for all the different CSR groups, except Employee and Governance. In terms of the change in KLD scores, firms have positive mean values, except $\Delta$ All KLD (neg). In particular, the CSR change is the highest for All, Society and Employee areas, and the lowest for Environment and Governance.

\section{Initial analyses}

Figure 1 displays the annual mean values of different KLD issue areas for the period 2003-2012. CSR in firms doesn't change significantly throughout the years until 2008. From 2008 onwards, firms increase their KLD scores and improve their CSR. Specifically, All KLD reaches to 2.5 by 2012 which is a two-point increase in overall CSR in firms. While Environment KLD score drops to 0.5 in 2012, Governance KLD and Society KLD increase by 0.5 and 1.3 points, respectively. Employee KLD displays a big jump from -0.5 to 1.5 by 2012 . This figure shows the increasing trend across companies in investing CSR, particularly in employee relations.

Figure 2 presents the annual mean changes in SRI fund ownership and All KLD score between 2003 and 2012. The change in overall firm CSR shows a slightly increasing trend until recent years. Starting 2008, the change in All KLD score jumps considerably to highly positive values which indicates firms improve their CSR. Interestingly, the changes in SRI fund ownership also increase from 30 to $60 \%$ by 2012 . This analysis reveals a positive link between firm CSR and SRI mutual fund investment throughout the years.

Table 2 presents the changes in SRI mutual fund ownership in firms regarding the different levels of firm CSR and Fund CSR Sensitivity. Mutual funds increase their ownership in the firms with a high overall CSR score by $57 \%$ if they are highly sensitive to the CSR practices. The funds with low CSR sensitivity still increase their investment in those high CSR firms about $30 \%$. The ownership difference between funds with high and 


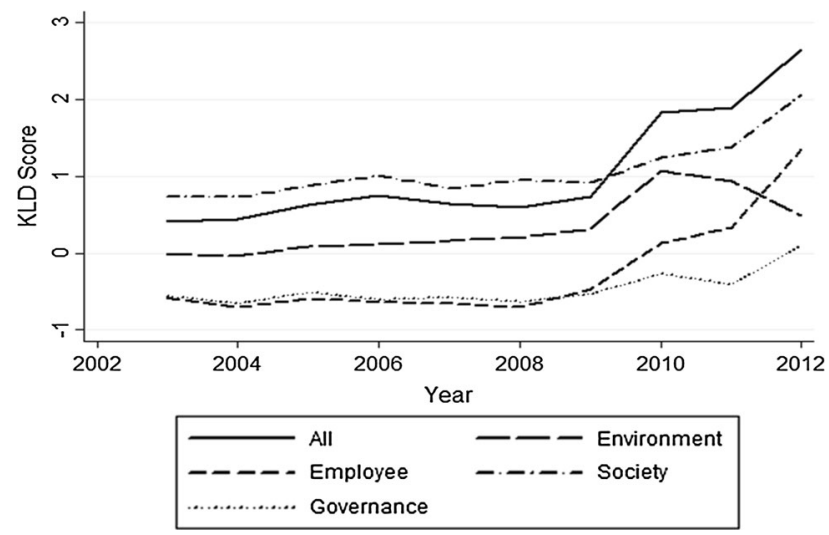

Fig. 1 Firm CSR Scores over Time by Different Issue Areas. This figure displays CSR by different issue areas (All, Employee, Society, Environment, and Governance) measured in firms' KLD scores for the period 2003-2012. The KLD score in each area is "KLD level (pos)" minus "KLD level (neg)" in that area. KLD level (pos) is the total number of "Strengths" relevant to the given issue. KLD level (neg) is the total number of "Concerns" relevant to the given issue

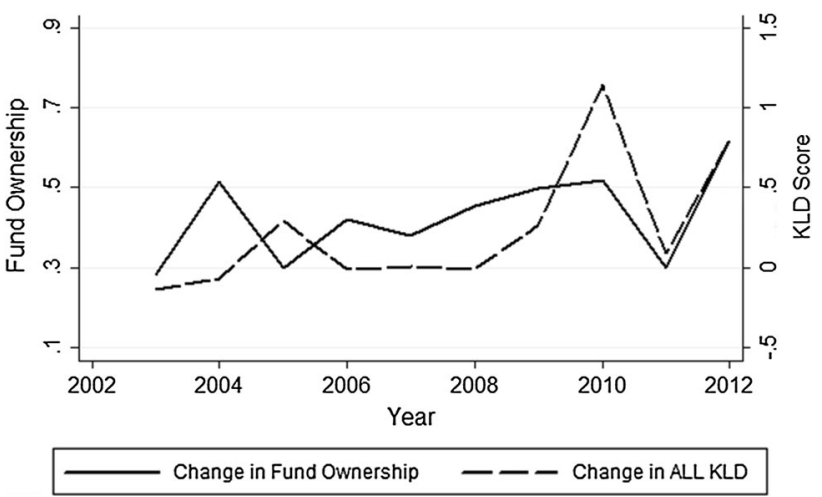

Fig. 2 Changes in Firm KLD Scores and SRI Mutual Funds' Ownership. The figure shows the changes in SRI fund ownership along with the changes in overall firm KLD score for the period 2003-2012. The change refers to the difference in each measure between the current year and the prior year

low CSR sensitivity is only $5 \%(=37-32 \%)$ for the firms with a low overall CSR score. The impact of high Fund CSR Sensitivity and high firm CSR score on the fund investment is more pronounced for Employee area of CSR. Highly sensitive funds invest more by $70 \%$ in companies when firms improve their employee relations via CSR practices. Funds also increase their ownership in firms by 62, 63, and $51 \%$ when those firms score high in Society, Environment, and Governance areas of CSR, respectively. Funds with a high or a low CSR sensitivity invest similarly in firms with a low CSR score in different issue areas. The differences are $3 \%(=38-35 \%), 11 \%(=39-28 \%), 11 \%(=42-30 \%)$, and $9 \%$ $(=40-31 \%)$ for Employee, Society, Environment, and Governance areas of CSR, respectively. Overall, the findings in Table 2 imply that funds always invest more when they are highly sensitive to CSR practices in firms. They increase their ownership in firms 
Table 2 Changes in SRI fund ownership by firm CSR score and fund CSR sensitivity
The table examines the mean values of percentage changes in SRI mutual fund ownership by the levels in CSR Score and CSR Fund Sensitivity. There are five different CSR issue areas: All, Employee, Society, Environment, and Governance. Firm CSR Score is High (Low) if the firm KLD level is in the top (bottom) quartile of the sample. Fund CSR Sensitivity is High (Low) if the funds' CSR sensitivity is in the top (bottom) quartile of the sample. Details of Fund CSR Sensitivity are available in Table A.3, variable definition. Change in SRI Ownership refers the difference in mutual funds' ownership in a firm between the current and the prior year

\begin{tabular}{|c|c|c|c|}
\hline CRS issue area & $\begin{array}{l}\text { Firm } \\
\text { CSR score }\end{array}$ & $\begin{array}{l}\text { Fund } \\
\text { CSR sensitivity }\end{array}$ & $\begin{array}{l}\text { Change in } \\
\text { SRI ownership (\%) }\end{array}$ \\
\hline \multirow[t]{4}{*}{ All } & \multirow[t]{2}{*}{ High } & High & 57.23 \\
\hline & & Low & 30.26 \\
\hline & \multirow[t]{2}{*}{ Low } & High & 37.41 \\
\hline & & Low & 32.11 \\
\hline \multirow[t]{4}{*}{ Employee } & \multirow[t]{2}{*}{ High } & High & 70.39 \\
\hline & & Low & 22.85 \\
\hline & \multirow[t]{2}{*}{ Low } & High & 38.05 \\
\hline & & Low & 35.05 \\
\hline \multirow[t]{4}{*}{ Society } & \multirow[t]{2}{*}{ High } & High & 62.26 \\
\hline & & Low & 31.99 \\
\hline & \multirow[t]{2}{*}{ Low } & High & 39.51 \\
\hline & & Low & 27.85 \\
\hline \multirow[t]{4}{*}{ Environment } & \multirow[t]{2}{*}{ High } & High & 63.34 \\
\hline & & Low & 15.35 \\
\hline & \multirow[t]{2}{*}{ Low } & High & 42.96 \\
\hline & & Low & 30.97 \\
\hline \multirow[t]{4}{*}{ Governance } & \multirow[t]{2}{*}{ High } & High & 51.02 \\
\hline & & Low & 31.06 \\
\hline & \multirow[t]{2}{*}{ Low } & High & 40.49 \\
\hline & & Low & 31.46 \\
\hline
\end{tabular}

in a greater scale when those firms have a higher CSR score. In general, firms receive less investment from SRI mutual funds if those firms are less socially conscious. ${ }^{7}$

\section{The empirical methodology}

I use the fixed effects panel regression model. I control for the potential omitted variables that differ between firm-fund observations but constant over time because I have a large sample of firm-fund observations while the time interval is 10 years (2003-2012). Firm KLD scores may not affect investment decisions of funds immediately. Hence, I use the changes in KLD scores rather than the scores themselves and also 1 year lagged values of firm control variables. I control for the potential effect coming from the changes in firm CSR which may partially explain the main relationship. Hence, I include $\Delta$ All KLD, $\Delta$ Employee KLD, $\Delta$ Society KLD, $\Delta$ Environment KLD, and $\Delta$ Governance KLD in the main model. The main variable of interest is the interaction of Fund CSR Sensitivity and KLD Score changes in firms. With this measure of fund-adjusted firm CSR changes, I can identify how SRI mutual funds decide their ownership in those companies. ${ }^{8}$ These

\footnotetext{
7 I conduct the same analysis using the changes in Firm CSR Score and Fund CSR Sensitivity instead of the levels. I obtain similar results.

8 The literature examines the relation between SRI mutual funds and firm CSR using only the changes in firm KLD scores. This approach fails to address the sensitivity of SRI funds while making their investment decisions. Additionally, I build a model similar to the one in literature and compare my results to the findings of that model. The methodology is given in Appendix.
} 
predictor variables are All Sensitivity $* \Delta$ All KLD, Employee Sensitivity * $\Delta$ Employee KLD, Society Sensitivity $* \Delta$ Society KLD, Environment Sensitivity * $\Delta$ Environment KLD, and Governance Sensitivity $* \Delta$ Governance KLD. The Fund CSR Sensitivity ratios have unique values for each SRI mutual fund. They do not vary through time for each fund, but they differ from one fund to another. On the contrary, " $\triangle$ KLD" values change over time and also for each firm. Since the main predictor variables are at the firm-fund-year level, and they are the interaction of CSR Sensitivity and $\Delta$ KLD terms, the variation to estimate those variables is coming from funds, firms and the time. Contrary to that, the variation only in firms and years is used to estimate $\Delta$ KLD terms in the analysis.

I explore whether funds take firm KLD score changes into account while deciding on their ownership in firms, and if so, how big is the magnitude of that reaction. Therefore, I use the percentage changes in SRI mutual funds' ownership in those firms between consecutive years. The model comprises year and Fama-French industry dummies. Standard errors are clustered by funds and firms. The main model is stated as follows:

$$
\begin{aligned}
Y_{i, t}= & \alpha+\beta * W_{i, t}+\pi * X_{i, t}+\phi * X_{i, t} * W_{i, t}+\sum_{l=1}^{10} \gamma_{l} * \text { FirmControls }_{i, t-1, l} \\
& +\sum_{k=1}^{2} \delta_{k} * \text { FundControls } s_{i, t, k}+\mu_{i, t}
\end{aligned}
$$

where $\mathrm{Y}$ is the percentage change in SRI mutual fund ownership; W is the Fund CSR Sensitivity ratio for different firm CSR areas; $X$ is firm $\triangle$ KLD scores for the different CSR areas; the firm-fund observation is $\mathrm{i}=1, \ldots, \mathrm{N}$; the entire period is $\mathrm{t}=2003, \ldots, 2012$; the number of firm control variables is $1=1, \ldots, 10$; the number of fund control variables is $\mathrm{k}=1,2$; and $\alpha, \beta, \pi, \varphi, \gamma, \delta, \mu$ are the coefficients of the constant term, Fund CSR Sensitivity ratio, firm $\triangle$ KLD scores for the different CSR areas, the interaction of Fund CSR Sensitivity and $\Delta$ KLD scores, firm controls, fund controls, and the error term, respectively.

I also examine SRI funds' responses to the changes in specific KLD criteria, such as "KLD Concerns" and "KLD Strengths". As a part of the main model, I use two additional predictor variables, All Sensitivity * $\Delta$ All KLD (pos) and All Sensitivity * $\Delta$ All KLD (neg). In the analysis, I control for the score changes in KLD (pos) and KLD (neg) via $\Delta$ All KLD (pos) and $\Delta$ All KLD (neg).

In a separate model, I examine only the years in which a new SRI mutual fund emerges and starts investing. The sample contains only 1 year (the emergent year) for each fund. I analyse each new fund individually. I use the OLS regression model and study the ownership of that new fund in relation to its CSR sensitivity and firm CSR changes.

I also construct an alternative sensitivity measure to examine a broader range of mutual funds. I use the holdings data from Thomson Reuters to estimate sensitivity for each fund by running an ARIMA $(1,1,1)$ time series regression of changes in portfolio weights on changes in firm CSR. The funds' previous investment habits may reveal the level of their responsiveness towards the practices in different firm CSR areas. The ARIMA $(1,1,1)$ model captures this relation. I repeat this analysis individually for All, Employee, Society, Environment, and Governance areas of CSR. I obtain each firm's coefficient estimate as the fund's sensitivity to CSR. I repeat the main analysis using these new sensitivity variables and a larger sample of mutual funds.

In further analyses, I test whether SRI mutual funds succeed to improve their portfolio performance after they increase their ownership in those firms. For each fund, I construct a 
portfolio of stocks based on either increased or decreased investment of the fund in those stocks. I use the OLS regression model with "Invested" as the independent variable, and "Portfolio Return" as the dependent variable. In order to control for risk, I use the weighted average of betas of the stocks in each portfolio. I control for shareholder activism using the total number of activism proposals by SRI Funds in the board meetings per firm per year. I also include other fund control variables in the model. The time span is between 2003 and 2012. ${ }^{9}$ Standard errors are clustered by funds. The model is specified as follows:

$$
\begin{aligned}
Y_{j, t}= & \alpha+\beta * X_{j, t}+\gamma * \text { PortfolioBeta }_{j, t}+\lambda * \text { FundActivism }_{j, t} \\
& +\sum_{k=1}^{2} \delta_{k} * \text { FundControls }_{j, t, k}+\mu_{j, t}
\end{aligned}
$$

where $\mathrm{Y}$ is the portfolio return of stocks; $\mathrm{X}$ is Invested dummy variable; the fund observation is $\mathrm{j}=1, \ldots, \mathrm{M}$; the entire period is $\mathrm{t}=2003, \ldots, 2012$; the number of fund control variables is $\mathrm{k}=1,2$; and $\alpha, \beta, \gamma, \lambda, \delta, \mu$ are the coefficients of the constant term, Portfolio Return, Invested, Portfolio Beta, Fund Activism, fund controls, and the error term, respectively.

\section{Main results and further analyses}

\subsection{Multivariate analyses on the SRI Funds' investment decision}

Table 3 provides results for SRI mutual fund ownership changes in regards to the changes in firm KLD measures. In Column I, $\Delta$ All KLD has statistically insignificant estimates suggesting the changes in firm overall CSR alone doesn't have an influence on SRI funds' investments. Once $\Delta$ All KLD interacts with All Sensitivity, then I obtain statistically significant and positive results. SRI funds with overall CSR sensitivity increase their ownership by $10.1 \%$ in firms when those companies improve their overall CSR score by one point. Particularly, an increase in "All Sensitivity * $\Delta$ All KLD" by one standard deviation leads to a jump in the fund ownership by $15.1 \%(=1.49 * 0.101)$. In Column II, findings indicate that the SRI funds' investment decision is only influenced by "All Sensitivity * $\Delta$ All KLD (pos)" while $\Delta$ All KLD (pos) alone can't produce significant results. Specifically, improvements in positive aspects of the firm KLD measure by one point result in an increase in funds' ownership by $5.1 \%$ if those funds are sensitive to CSR practices. In other words, the funds having CSR sensitivity invest in firms more by $12.8 \%$ $(=2.50 * 0.051)$ when those firms increase All KLD (pos) score by one standard deviation. The insignificant findings in Column III imply that the mutual fund investment is not affected by the deteriorated CSR conditions in firms. Column IV presents results from the model including both "KLD Strengths" and "KLD Concerns" measures. Contrary to insignificant estimates for "All Sensitivity * $\Delta$ All KLD (neg)", the significant and positive findings for "All Sensitivity* $\Delta$ All KLD (pos)" indicate that SRI mutual funds increase their ownership in the firms with improved CSR. In particular, the funds invest more by $5.2 \%$ when firms improve All KLD (pos) score by one point.

Table 4 presents the analyses to reveal the specific CSR channels through which the SRI funds' investment decision is influenced. Statistically significant and positive results in Column I indicate that the funds having CSR sensitivity increase their ownership by

\footnotetext{
${ }^{9}$ I repeat the same analysis for each year individually to control for any influence by a specific year.
} 
Table 3 SRI fund ownership decision regarding firm CSR

\begin{tabular}{|c|c|c|c|c|}
\hline & \multicolumn{4}{|c|}{$\%$ Change in ownership } \\
\hline & I & II & III & IV \\
\hline All sensitivity $* \Delta$ All KLD & $\begin{array}{l}0.101 * * \\
(0.045)\end{array}$ & & & \\
\hline$\Delta$ All KLD & $\begin{array}{l}-0.051 \\
(0.032)\end{array}$ & & & \\
\hline All sensitivity $* \Delta$ All KLD (pos) & & $\begin{array}{l}0.051 * * \\
(0.026)\end{array}$ & & $\begin{array}{l}0.053 * * \\
(0.026)\end{array}$ \\
\hline$\Delta$ All KLD (pos) & & $\begin{array}{l}-0.055 \\
(0.037)\end{array}$ & & $\begin{array}{l}-0.057 \\
(0.037)\end{array}$ \\
\hline All sensitivity $* \Delta$ All KLD (neg) & & & $\begin{array}{l}-0.049 \\
(0.037)\end{array}$ & $\begin{array}{l}-0.050 \\
(0.037)\end{array}$ \\
\hline$\Delta$ All KLD (neg) & & & $\begin{array}{l}0.049 \\
(0.052)\end{array}$ & $\begin{array}{l}0.051 \\
(0.051)\end{array}$ \\
\hline Firm Size & $\begin{array}{l}0.009 \\
(0.170)\end{array}$ & $\begin{array}{l}0.004 \\
(0.170)\end{array}$ & $\begin{array}{l}0.029 \\
(0.171)\end{array}$ & $\begin{array}{l}0.009 \\
(0.171)\end{array}$ \\
\hline $\mathrm{M} / \mathrm{B}$ & $\begin{array}{l}-0.078 \\
(0.058)\end{array}$ & $\begin{array}{l}-0.079 \\
(0.058)\end{array}$ & $\begin{array}{l}-0.078 \\
(0.058)\end{array}$ & $\begin{array}{l}-0.078 \\
(0.058)\end{array}$ \\
\hline Profitability & $\begin{array}{l}-0.037 \\
(0.052)\end{array}$ & $\begin{array}{l}-0.036 \\
(0.052)\end{array}$ & $\begin{array}{l}-0.034 \\
(0.051)\end{array}$ & $\begin{array}{l}-0.037 \\
(0.052)\end{array}$ \\
\hline Leverage & $\begin{array}{l}-0.105^{* *} \\
(0.053)\end{array}$ & $\begin{array}{l}-0.104 * * \\
(0.053)\end{array}$ & $\begin{array}{l}-0.104 * * \\
(0.053)\end{array}$ & $\begin{array}{l}-0.105^{* *} \\
(0.053)\end{array}$ \\
\hline Volatility & $\begin{array}{l}0.033 \\
(0.037)\end{array}$ & $\begin{array}{l}0.032 \\
(0.037)\end{array}$ & $\begin{array}{l}0.033 \\
(0.037)\end{array}$ & $\begin{array}{l}0.033 \\
(0.037)\end{array}$ \\
\hline Growth & $\begin{array}{l}0.039 \\
(0.061)\end{array}$ & $\begin{array}{l}0.040 \\
(0.061)\end{array}$ & $\begin{array}{l}0.043 \\
(0.061)\end{array}$ & $\begin{array}{l}0.038 \\
(0.061)\end{array}$ \\
\hline Dividend & $\begin{array}{l}-0.061^{*} \\
(0.034)\end{array}$ & $\begin{array}{l}-0.063^{*} \\
(0.034)\end{array}$ & $\begin{array}{l}-0.062^{*} \\
(0.034)\end{array}$ & $\begin{array}{l}-0.061^{*} \\
(0.034)\end{array}$ \\
\hline Cash & $\begin{array}{l}-0.058 \\
(0.086)\end{array}$ & $\begin{array}{l}-0.060 \\
(0.086)\end{array}$ & $\begin{array}{l}-0.057 \\
(0.086)\end{array}$ & $\begin{array}{l}-0.058 \\
(0.086)\end{array}$ \\
\hline $\mathrm{R} \& \mathrm{D}$ & $\begin{array}{l}-0.032 \\
(0.041)\end{array}$ & $\begin{array}{l}-0.033 \\
(0.040)\end{array}$ & $\begin{array}{l}-0.032 \\
(0.041)\end{array}$ & $\begin{array}{l}-0.032 \\
(0.041)\end{array}$ \\
\hline $\mathrm{HHI}$ & $\begin{array}{l}0.030 \\
(0.032)\end{array}$ & $\begin{array}{l}0.032 \\
(0.032)\end{array}$ & $\begin{array}{l}0.034 \\
(0.032)\end{array}$ & $\begin{array}{l}0.030 \\
(0.032)\end{array}$ \\
\hline Fund return & $\begin{array}{l}0.623 * * * \\
(0.140)\end{array}$ & $\begin{array}{l}0.618 * * * \\
(0.140)\end{array}$ & $\begin{array}{l}0.618^{* * *} \\
(0.139)\end{array}$ & $\begin{array}{l}0.623 * * * \\
(0.140)\end{array}$ \\
\hline Fund size & $\begin{array}{l}-0.443^{* * *} \\
(0.110)\end{array}$ & $\begin{array}{l}-0.442 * * * \\
(0.110)\end{array}$ & $\begin{array}{l}-0.441^{* * *} \\
(0.111)\end{array}$ & $\begin{array}{l}-0.444 * * * \\
(0.110)\end{array}$ \\
\hline Constant & $\begin{array}{l}1.083 * * * \\
(0.187)\end{array}$ & $\begin{array}{l}1.072^{* * * *} \\
(0.188)\end{array}$ & $\begin{array}{l}1.067^{* * * *} \\
(0.186)\end{array}$ & $\begin{array}{l}1.084 * * * \\
(0.187)\end{array}$ \\
\hline Fixed effects & YES & YES & YES & YES \\
\hline Year and industry dummies & YES & YES & YES & YES \\
\hline Observations & 9301 & 9301 & 9301 & 9301 \\
\hline
\end{tabular}


Table 3 continued

\begin{tabular}{lllll}
\hline & \multicolumn{4}{l}{$\%$ Change in ownership } \\
\cline { 2 - 5 } & I & II & III & IV \\
\hline Adjusted R-squared & 0.040 & 0.039 & 0.039 & 0.039 \\
\hline
\end{tabular}

The table presents estimates from fixed effects panel regressions of changes in SRI fund ownership in firms on changes in firm All KLD measure. Dependent variable is the percentage change in SRI fund's ownership in each firm's shares at the given year. Key predictor variables are the interaction terms of $\Delta$ All KLD, $\Delta$ All KLD (pos), and $\triangle$ All KLD (neg) with SRI funds' overall CSR sensitivity. Observations are based on fundfirm-year level. All regressions include 1 year lagged firm and fund control variables. Variable definitions are available in Table A.3, Appendix. Fixed effects are at the firm-fund level and year fixed effects are included. Standard errors are clustered at the fund-firm level. The *** indicates statistical significance at the $1 \%$ level

$10.1 \%$ if firms' overall CSR improves by one point. Column II and Column III show significant and negative estimates for $\Delta$ Employee KLD and $\Delta$ Society KLD. The negative results may be counterintuitive, but the interpretation of these estimates is incomplete and inaccurate without considering the funds' CSR sensitivity. These results cannot explain the fund investment decision sufficiently because the change in Employee and Society areas of firm CSR may not be enough to influence SRI funds without considering whether those funds are sensitive to the practices in those specific CSR areas. Statistically significant and positive findings for "Employee Sensitivity * $\Delta$ Employee KLD" and "Society Sensitivity $* \Delta$ Society KLD" suggest funds invest in firms more by 34.4 and $29.3 \%$, respectively, when those firms engage practices which improves employee relations and help the society. This implies SRI funds that care about Employee and Society areas of CSR increase their ownership in firms by $17.2 \%(=0.499 * 0.344)$ and $16.6 \%(=0.568 * 0.293)$ when firms have higher CSR scores in those areas by one standard deviation. Column IV suggests an increase in the fund ownership by $26.8 \%$ when "Environment Sensitivity * $\Delta$ Environment KLD" rises by one point. Particularly, SRI mutual funds that are sensitive to environment issues invest more by $10 \%(=0.377 * 0.268)$ in the firms having Environment CSR score improved by one standard deviation. The significant and positive results for "Governance Sensitivity * $\Delta$ Governance KLD" in Column V indicate that SRI fund investment rises by 46.8 and $10.4 \%(=0.233 * 0.468)$ when firms increase the CSR score in the Governance area by one point and one standard deviation, respectively. ${ }^{10}$

Considering the total number of observations in the analyses, I check the degree of freedom when the firm-fund fixed effect is included. Also, the firm-fund fixed effect might impact the main findings. Hence, I exclude these fixed effects and run the main model again. In those untabulated analyses, I obtain robust results. In particular, an increase in "All Sensitivity * $\Delta$ All KLD" by one standard deviation leads to a jump in the fund ownership by $15.2 \%(=1.49 * 0.102)$. The findings are not driven by the firm-fund fixed effect.

It may be argued that the funds' CSR sensitivity is so influential on their investments in firms that the interaction effect via the independent variable on the dependent variable is impossible not to be positive. This is not a concern in this study. Table A.2, Online

\footnotetext{
${ }^{10}$ Following the literature, I also use the model with firm KLD score changes alone as the main variable of interest. Findings are given in Table A.1, Appendix. I observe the impact of firm CSR changes on SRI fund ownership becomes weaker and only partially significant. This gives support to the accuracy of my main model using Fund CSR Sensitivity and Firm KLD score together.
} 
Table 4 SRI fund ownership decision regarding different issue areas of CSR

\begin{tabular}{|c|c|c|c|c|c|}
\hline & \multicolumn{5}{|c|}{$\%$ Change in ownership } \\
\hline & I & II & III & IV & $\mathrm{V}$ \\
\hline All sensitivity $* \Delta$ All KLD & $\begin{array}{l}0.101 * * \\
(0.045)\end{array}$ & & & & \\
\hline$\Delta$ All KLD & $\begin{array}{l}-0.0514 \\
(0.032)\end{array}$ & & & & \\
\hline Employee sensitivity $* \Delta$ Employee KLD & & $\begin{array}{l}0.344 * * * \\
(0.124)\end{array}$ & & & \\
\hline$\Delta$ Employee KLD & & $\begin{array}{l}-0.143 * * \\
(0.058)\end{array}$ & & & \\
\hline Society sensitivity $* \Delta$ Society KLD & & & $\begin{array}{l}0.293 * * \\
(0.135)\end{array}$ & & \\
\hline$\Delta$ Society KLD & & & $\begin{array}{l}-0.107 * * \\
(0.052)\end{array}$ & & \\
\hline $\begin{array}{l}\text { Environment sensitivity } * \Delta \text { Environment } \\
\quad \text { KLD }\end{array}$ & & & & $\begin{array}{l}0.268 * * \\
(0.121)\end{array}$ & \\
\hline$\Delta$ Environment KLD & & & & $\begin{array}{l}-0.042 \\
(0.059)\end{array}$ & \\
\hline Governance sensitivity $* \Delta$ Governance KLD & & & & & $\begin{array}{l}0.468 * * \\
(0.193)\end{array}$ \\
\hline$\Delta$ Governance KLD & & & & & $\begin{array}{l}-0.076 \\
(0.058)\end{array}$ \\
\hline Constant & $\begin{array}{l}1.083 * * * \\
(0.187)\end{array}$ & $\begin{array}{l}1.088 * * * \\
(0.187)\end{array}$ & $\begin{array}{l}1.062 * * * \\
(0.187)\end{array}$ & $\begin{array}{l}1.063 * * * \\
(0.189)\end{array}$ & $\begin{array}{l}1.073^{* * *} \\
(0.188)\end{array}$ \\
\hline Firm and fund controls & YES & YES & YES & YES & YES \\
\hline Fixed effects & YES & YES & YES & YES & YES \\
\hline Year and industry dummies & YES & YES & YES & YES & YES \\
\hline Observations & 9301 & 9301 & 9301 & 9301 & 9301 \\
\hline Adjusted R-squared & 0.040 & 0.040 & 0.039 & 0.039 & 0.040 \\
\hline
\end{tabular}

The table presents estimates from fixed effects panel regressions of changes in SRI fund ownership in firms on changes in different firm KLD measures. Dependent variable is the percentage change in SRI fund's ownership in each firm's shares at the given year. Key predictor variables are the interaction terms of $\Delta$ All KLD, $\Delta$ Employee KLD, $\Delta$ Society KLD, $\Delta$ Environment KLD, and $\Delta$ Governance KLD with Fund CSR Sensitivity in the same issue area. Observations are based on fund-firm-year level. All regressions include 1 year lagged firm and fund control variables. Variable definitions are available in Table A.3, Appendix. Fixed effects are at the firm-fund level and year fixed effects are included. Standard errors are clustered at the fund-firm level. The $* * *$ indicates statistical significance at the $1 \%$ level

Appendix, shows the correlation between the changes in SRI ownership and firm KLD measures for different levels of Fund CSR Sensitivity. Regardless how sensitive SRI funds are (high, medium, or low), the correlation between mutual fund ownership and the main focal variables in this study does not change significantly. Therefore, the positive impact of the interaction (independent) variable on the changes in SRI fund ownership should not be due to any bias or mechanic effect by the funds' perception of CSR. 
The findings in Table 4 imply that the improvement in employee relations in firms is the main channel to attract SRI funds' investment. Funds increase their ownership by $17.2 \%$ (contrary to $16.6,10$, and $10.4 \%$ ) in the firms that engage in CSR practices to improve specifically employee related aspects rather than Society, Environment, and Governance areas of CSR. The firms investing in their employees signal high CSR which enhances firm's reputation and prestige. As suggested by Baron (2008) and Edmands (2012), these specific improvements boost loyalty, employee contribution, and motivation through which productivity, firm performance and firm value increase. Due to these reasons and the potential firm value maximizing effect, SRI mutual funds that are sensitive to employee and human issues may be interested more in those firms while they decide on their investments.

\subsection{Further analyses}

\subsubsection{Endogeneity concern-new fund analysis}

In this study, the main endogeneity concern is the reverse causality. In general, firms engage in different CSR practices due to their operations first, and then SRI mutual funds observe those CSR activities in firms and form their investment decisions accordingly. Hence, CSR should impact the SRI ownership in firms, and the way of causality in this relationship should be from firm CSR towards SRI holdings in those firms. One can argue that the causality might be in the opposite direction. Firms could have examined the funds' previous investment choices and deliberately engaged in specific CSR practices just to attract those funds. Thus, SRI ownership might have led to firm CSR activities. Because of this reverse causality, firms might have decided on CSR endogenously. I address that issue using the changes (not the level) in ownership and CSR measures, as well as, the lagged values of control variables. As a further analysis, I examine only the years in which a new SRI fund emerges. Since firms don't have prior knowledge of new SRI funds, they could not have anticipated these new funds' investment. Hence, the initial investment by new funds cannot affect firm CSR practices. In contrast, new SRI mutual funds pick firms according to their CSR scores. Thus, the way of influence is only from firm CSR towards new funds' ownership decision. Table 5 provides statistically significant ${ }^{11}$ and positive results for the main independent variables. Particularly, new SRI funds that are responsive to CSR practices increase their ownership in firms by $2.2,4.5,3.7,2.4$, and $7 \%$ when those firms have higher KLD scores by one point in All, Employee, Society, Environment, and Governance areas of CSR, respectively. These findings indicate the robustness of the original results after controlling for the potential endogeneity issue.

Another form of endogeneity is omitted variables. It may be that the world is changing such that individuals value social responsibility greater over time. This may cause both funds to change their investments to focus on CSR firms, and firms to increase their CSR. If this was the case, then all SRI mutual funds and the firms should be affected. Hence, such a case should not cause the variation in the funds and the firms in terms of CSR; and the main results of my analyses should remain unaffected. Moreover, I include year fixed effects in the analyses which should control for such omitted time dependent factors.

11 The results are significant for all main explanatory variables with an exception for Environment Sensitivity $* \Delta$ Environment KLD. 
Table 5 Analysis with new SRI mutual funds

\begin{tabular}{|c|c|c|c|c|c|}
\hline & \multicolumn{5}{|c|}{$\%$ Change in ownership } \\
\hline & I & II & III & IV & $\mathrm{V}$ \\
\hline All sensitivity $* \Delta$ All KLD & $\begin{array}{l}0.022^{*} \\
(0.012)\end{array}$ & & & & \\
\hline All sensitivity & $\begin{array}{l}-0.219 * * * \\
(0.046)\end{array}$ & & & & \\
\hline$\Delta$ All KLD & $\begin{array}{l}-0.011 \\
(0.009)\end{array}$ & & & & \\
\hline $\begin{array}{l}\text { Employee sensitivity } * \Delta \text { Employee } \\
\text { KLD }\end{array}$ & & $\begin{array}{l}0.045^{* *} \\
(0.018)\end{array}$ & & & \\
\hline Employee sensitivity & & $\begin{array}{l}-0.223^{* * * *} \\
(0.046)\end{array}$ & & & \\
\hline$\Delta$ Employee KLD & & $\begin{array}{l}-0.017 * * \\
(0.008)\end{array}$ & & & \\
\hline Society sensitivity $* \Delta$ Society KLD & & & $\begin{array}{l}0.037 * * \\
(0.019)\end{array}$ & & \\
\hline Society sensitivity & & & $\begin{array}{l}-0.308 * * * \\
(0.065)\end{array}$ & & \\
\hline$\Delta$ Society KLD & & & $\begin{array}{l}-0.013^{*} \\
(0.008)\end{array}$ & & \\
\hline $\begin{array}{l}\text { Environment sensitivity } * \Delta \\
\text { Environment KLD }\end{array}$ & & & & $\begin{array}{l}0.024 \\
(0.043)\end{array}$ & \\
\hline Environment sensitivity & & & & $\begin{array}{l}-0.215^{* * *} \\
(0.046)\end{array}$ & \\
\hline$\Delta$ Environment KLD & & & & $\begin{array}{l}0.002 \\
(0.019)\end{array}$ & \\
\hline $\begin{array}{l}\text { Governance sensitivity } * \Delta \\
\text { Governance KLD }\end{array}$ & & & & & $\begin{array}{l}0.070 * * \\
(0.033)\end{array}$ \\
\hline Governance sensitivity & & & & & $\begin{array}{l}-0.356^{* * *} \\
(0.073)\end{array}$ \\
\hline$\Delta$ Governance KLD & & & & & $\begin{array}{l}-0.005 \\
(0.009)\end{array}$ \\
\hline Constant & $\begin{array}{l}0.246 * * * \\
(0.061)\end{array}$ & $\begin{array}{l}0.175 * * * \\
(0.054)\end{array}$ & $\begin{array}{l}0.188 * * * \\
(0.055)\end{array}$ & $\begin{array}{l}0.175^{* * * *} \\
(0.056)\end{array}$ & $\begin{array}{l}0.182 * * * \\
(0.054)\end{array}$ \\
\hline Control variables & YES & YES & YES & YES & YES \\
\hline Year and industry dummies & YES & YES & YES & YES & YES \\
\hline Observations & 704 & 704 & 704 & 704 & 704 \\
\hline Adjusted R-squared & 0.257 & 0.248 & 0.252 & 0.224 & 0.262 \\
\hline
\end{tabular}

The table presents estimates from OLS regressions of new SRI fund ownership in firms on changes in different firm KLD measures. Dependent variable is new SRI fund's ownership percentage in each firm's shares at the emergent year. In the sample new funds emerge in 2004, 2005, 2007, and 2008. Key predictor variables are the interaction terms of $\Delta$ All KLD, $\Delta$ Employee KLD, $\Delta$ Society KLD, $\Delta$ Environment KLD, and $\Delta$ Governance KLD with Fund CSR Sensitivity in the same issue area. Observations are based on fundfirm-year level. All regressions include 1 year lagged control variables. Variable definitions are available in Table A.3, Appendix. Year and industry dummies are included. Standard errors are clustered at the fundfirm level. The *** indicates statistical significance at the $1 \%$ level 


\subsubsection{Larger sample and alternative sensitivity measure}

In this study, I create the CSR sensitivity measure using the US SIF database and lose several SRI mutual funds after I merge the data with Thomson Reuters' S12 holding data and CSRP. Further, I construct the sensitivity measure via a different method, so that I can include more mutual funds from Thomson Reuters' S12 holding data in my analysis. I use the holdings data to estimate sensitivity for each fund by running an ARIMA $(1,1,1)$ time series regression of changes in portfolio weights on changes in firm CSR. I repeat this exercise individually for each specific area of CSR, i.e. All, Employee, Society, Environment, and Governance. Each firm's coefficient estimate becomes the fund's sensitivity to CSR. Then, I conduct the main analysis using these new sensitivity variables and a larger sample of mutual funds.

Table 6 provides the results. The positive estimates for the main independent variables are statistically very significant. In particular, mutual funds that are sensitive to CSR, increase their investment in firms by $1.4,2,1.2,4.2$, and $1.9 \%$ when those companies improve their CSR level by one point in All, Employee, Society, Environment, and Governance areas, respectively. These findings confirm the validity of the original results (via 32 SRI funds) for a broader spectrum of mutual funds.

\subsubsection{Analysis with different measures on liquidity}

In the analyses, I control for the firm specific factors while investigating the relation between the SRI mutual fund ownership, firm CSR, and Fund CSR Sensitivity. However, these funds may have a bias towards the liquid stocks, and the trading activity of the firms' stocks may have an influence on their investment decision. Following Lesmond et al. (1999), and Amihud (2002), I construct different measures on liquidity, and control for that factor in the main model. "Amihud" is the yearly average of the ratio of absolute daily returns to daily trading volume of a firm's stocks. "ZERO" is the proportion of days with zero stock returns of a firm in a year. "LnVolume" is the natural logarithm of total trading volume of a firm's stocks. "Turnover" is the total trading volume of a firm's stocks over the average total number of shares outstanding in a year. " $\Delta$ Turnover" is the change in Turnover between the current year and the prior year. Table 7 provides the results. "All Sensitivity * $\Delta$ All KLD" has significant and positive coefficients after controlling for liquidity via different measures $(10.2,10.2,10.1,10.2$, and $10.6 \%$, respectively). These robust findings imply that the trading activity of the firms' stocks does not contribute to the SRI ownership significantly.

\subsubsection{Industry Analysis}

I further examine the effect of firm CSR and Fund CSR Sensitivity on the SRI mutual fund investment decision for different industry concentrations and industry groups. Although firms in different industries may improve their CSR, this may not be sufficient enough for SRI mutual funds to invest more in those firms correspondingly due to the possible fund preferences in certain industry types and high competitiveness. I construct two samples for the industry concentration using HHI: firms with HHI less than 0.05 are in the "Competitive Industry" sample while firms with HHI more than 0.450 are in the "Concentrated Industry" sample. Using Fama-French 49 industry classification, I construct 10 major industry groups: "Manufacturing, Construction, Mining \& Energy, Retail \& Wholesale, 
Table 6 Mutual fund investment regarding different CSR area via new sensitivity measure

\begin{tabular}{|c|c|c|c|c|c|}
\hline & \multicolumn{5}{|c|}{$\%$ Change in ownership } \\
\hline & I & II & III & IV & $\mathrm{V}$ \\
\hline All sensitivity $* \Delta$ All KLD & $\begin{array}{l}0.014 * * * \\
(0.001)\end{array}$ & & & & \\
\hline$\Delta$ All KLD & $\begin{array}{l}0.002 * * \\
(0.001)\end{array}$ & & & & \\
\hline Employee sensitivity $* \Delta$ Employee KLD & & $\begin{array}{l}0.020 * * * \\
(0.001)\end{array}$ & & & \\
\hline$\Delta$ Employee KLD & & $\begin{array}{l}0.004 * * \\
(0.002)\end{array}$ & & & \\
\hline Society sensitivity $* \Delta$ Society KLD & & & $\begin{array}{l}0.012 * * * \\
(0.001)\end{array}$ & & \\
\hline$\Delta$ Society KLD & & & $\begin{array}{l}0.001 \\
(0.001)\end{array}$ & & \\
\hline $\begin{array}{l}\text { Environment sensitivity } * \Delta \text { Environment } \\
\quad \text { KLD }\end{array}$ & & & & $\begin{array}{l}0.042 * * * \\
(0.002)\end{array}$ & \\
\hline$\Delta$ Environment KLD & & & & $\begin{array}{l}0.017 * * * \\
(0.003)\end{array}$ & \\
\hline Governance sensitivity $* \Delta$ Governance KLD & & & & & $\begin{array}{l}0.019 * * * \\
(0.001)\end{array}$ \\
\hline$\Delta$ Governance KLD & & & & & $\begin{array}{l}0.006 * * * \\
(0.002)\end{array}$ \\
\hline Constant & $\begin{array}{l}0.357 * * * \\
(0.012)\end{array}$ & $\begin{array}{l}0.357 * * * \\
(0.012)\end{array}$ & $\begin{array}{l}0.356 * * * \\
(0.012)\end{array}$ & $\begin{array}{l}0.355^{* * * *} \\
(0.012)\end{array}$ & $\begin{array}{l}0.356 * * * \\
(0.012)\end{array}$ \\
\hline Firm and fund controls & YES & YES & YES & YES & YES \\
\hline Fixed effects & YES & YES & YES & YES & YES \\
\hline Year and industry dummies & YES & YES & YES & YES & YES \\
\hline Observations & 1624,413 & $1,624,413$ & $1,624,413$ & $1,624,413$ & $1,624,413$ \\
\hline Adjusted R-squared & 0.062 & 0.063 & 0.062 & 0.063 & 0.063 \\
\hline
\end{tabular}

The table presents estimates from fixed effects panel regressions of changes in SRI fund ownership in firms on changes in different firm KLD measures. This analysis uses a new sensitivity measure for mutual funds which is obtained from an ARIMA $(1,1,1)$ regression of changes in funds' portfolio weights on changes in firm CSR. Dependent variable is the percentage change in SRI fund's ownership in each firm's shares at the given year. Key predictor variables are the interaction terms of $\Delta$ All KLD, $\Delta$ Employee KLD, $\Delta$ Society KLD, $\Delta$ Environment KLD, and $\Delta$ Governance KLD with Fund CSR Sensitivity in the same issue area. Observations are based on fund-firm-year level. All regressions include 1 year lagged firm and fund control variables. Definitions of the other variables are available in Table A.3, Appendix. Fixed effects are at the firm-fund level and year fixed effects are included. Standard errors are clustered at the fund-firm level. The *** indicates statistical significance at the $1 \%$ level

Telecommunication, Leisure, Business Services, Transportation, Personal Services, and Finance". I repeat the main analysis for each sample individually.

Table 8 presents the results. "All Sensitivity * $\Delta$ All KLD" has significant and positive findings for both competitive and concentrated industries. This indicates mutual funds that 
are sensitive to CSR activities do not differentiate between socially responsible firms according to their industry concentration. However, findings for different industry groups suggest those SRI mutual funds increase their ownership in firms operating only in certain industries. Results hold for large sectors, such as construction and finance, as well as, small industries, e.g. transportation and personal services. Firms in construction, transportation, personal services, and financial sector experience more SRI fund investment by 35.7, 78.8, 63, and $11.8 \%$, respectively, when these companies demonstrate better CSR practices and improve their overall KLD score by one point. The results demonstrate the industry preferences of SRI mutual funds for their investments, and hence, these findings may be useful for the firms operating in those industries and seeking external funding.

Table 7 Analysis with different measures on liquidity

\begin{tabular}{llllll}
\hline \multicolumn{7}{l}{$\%$ Change in ownership } & & \\
\cline { 2 - 6 } & I & II & III & IV & V \\
\hline All sensitivity * A All KLD & $0.102^{* *}$ & $0.102^{* *}$ & $0.101 * *$ & $0.102^{* *}$ & $0.106^{* *}$ \\
& $(0.046)$ & $(0.046)$ & $(0.045)$ & $(0.046)$ & $(0.048)$ \\
$\Delta$ All KLD & -0.051 & -0.052 & -0.051 & -0.052 & $-0.056^{*}$ \\
& $(0.032)$ & $(0.032)$ & $(0.032)$ & $(0.032)$ & $(0.034)$
\end{tabular}

Amihud

ZERO

LnVolume

(0.065)

Turnover

0.008

(0.022)

$\Delta$ Turnover

$0.032 *$

(0.019)

Constant

$1.213 * * *$

$1.220 * * *$

$1.436 * * *$

$1.204 * * *$

$1.444 * * *$

Firm and fund controls

(0.216)

(0.214)

(0.406)

(0.222)

(0.302)

Fixed effects

YES

YES

YES

YES

YES

Year and industry dummies

YES

YES

YES

YES

YES

YES

YES

YES

YES

YES

9301

9301

9301

9301

9301

Adjusted R-squared

0.040

0.039

0.039

0.039

0.047

The table presents estimates from fixed effects panel regressions of changes in SRI fund ownership in firms on changes in firm All KLD measure. This analysis includes different control variables for liquidity of the firms' stocks. Amihud is the yearly average of the ratio of absolute daily returns to daily trading volume of a firm's stocks. ZERO is the proportion of days with zero stock returns of a firm in a year. LnVolume is the natural logarithm of total trading volume of a firm's stocks. Turnover is the total trading volume of a firm's stocks over the total number of shares outstanding in a year. $\Delta$ Turnover is the change in Turnover between the current year and the prior year. Observations are based on fund-firm-year level. All regressions include 1 year lagged firm and fund control variables. Definitions of the other variables are available in Table A.3, Appendix. Fixed effects are at the firm-fund level and year fixed effects are included. Standard errors are clustered at the fund-firm level. The *** indicates statistical significance at the $1 \%$ level 


\subsubsection{CSR improvement by SRI mutual funds}

SRI funds may provide society an externality of improving CSR. As suggested by Sparkes and Cowton (2004), when firms are invested by highly socially conscious mutual funds, they can pressure those companies to engage in better CSR practices. If that is true, then one might observe a significant improvement of the firm's CSR score subsequent to such holding increase by SRI funds. Moreover, this influence by SRI on firm CSR might be more pronounced when those funds have high CSR sensitivity.

I examine the potential effect of SRI funds by testing whether the increase in Firm CSR Score averages (from current year to next year) is different from zero after SRI funds increase their ownership in those firms (from prior year to current year). In a separate test, I focus only on firms with a substantial increase in holdings (top $10 \%$ category). Lastly, I construct two samples with funds in top and bottom quintile of CSR sensitivity, respectively. I repeat the exercise using these SRI funds with very high (low) CSR sensitivity in order to reveal the significance of CSR sensitivity in this relationship. Table 9 presents the results. In Panel A, the statistically significant increases in CSR score averages indicate firms have better CSR practices after SRI mutual funds increase their holdings in those firms. In particular, the overall CSR score improves by 0.30 point next year when SRI ownership increases this year. The scores improve by $0.20,0.23,0.09$, and 0.04 points for employee, society, environment, and governance areas of CSR, respectively. Furthermore, the increase in CSR scores is even greater when SRI funds have a higher level of ownership in firms. These results give support to the idea of SRI involvement in firms through which CSR becomes stronger.

In Panel B, the increase in CSR score averages is greater when mutual funds with high CSR sensitivity invest in those firms. Specifically, overall CSR score rises by 0.68 point next year after a big increase in SRI holdings this year. Similarly, the scores increase by 0.31, 0.43, 0.16 and 0.09 points for employee, society, environment, and governance areas of CSR, respectively. These findings show significantly positive influence of high CSR sensitivity along with a high level of SRI involvement on CSR activities in firms. Supporting the previous findings, I obtain weaker and insignificant results in Panel C using SRI funds with low CSR sensitivity. When ethically less conscious mutual funds do not have sufficient involvement in CSR, they cannot affect the companies enough to improve CSR.

\subsubsection{SRI mutual fund performance}

I study the difference between the returns of the market and SRI funds' portfolios of stocks in which they increased their investments. Those funds are large companies and they are mainly traded in NASDAQ; hence, NASDAQ is chosen for the market return calculation. Table 10 shows the findings. Considering the whole sample, the portfolio of firms with increased ownership by SRI funds underperforms the market by $0.096 \%$. Similarly, the differences are negative and statistically significant for most of the individual years; this implies the underperformance of SRI portfolios. Contrary to the other years, funds' portfolios have a better return than NASDAQ in 2007, 2008, and 2011. These results indicate that SRI portfolios underperform the market in general; however, they have higher returns than the market during the crisis period.

Further, I analyze whether SRI mutual funds are successful with their choice of firms and improve their portfolio performance after they increase their ownership in those firms. Hence, I need to consider the firms in which these mutual funds increased their 


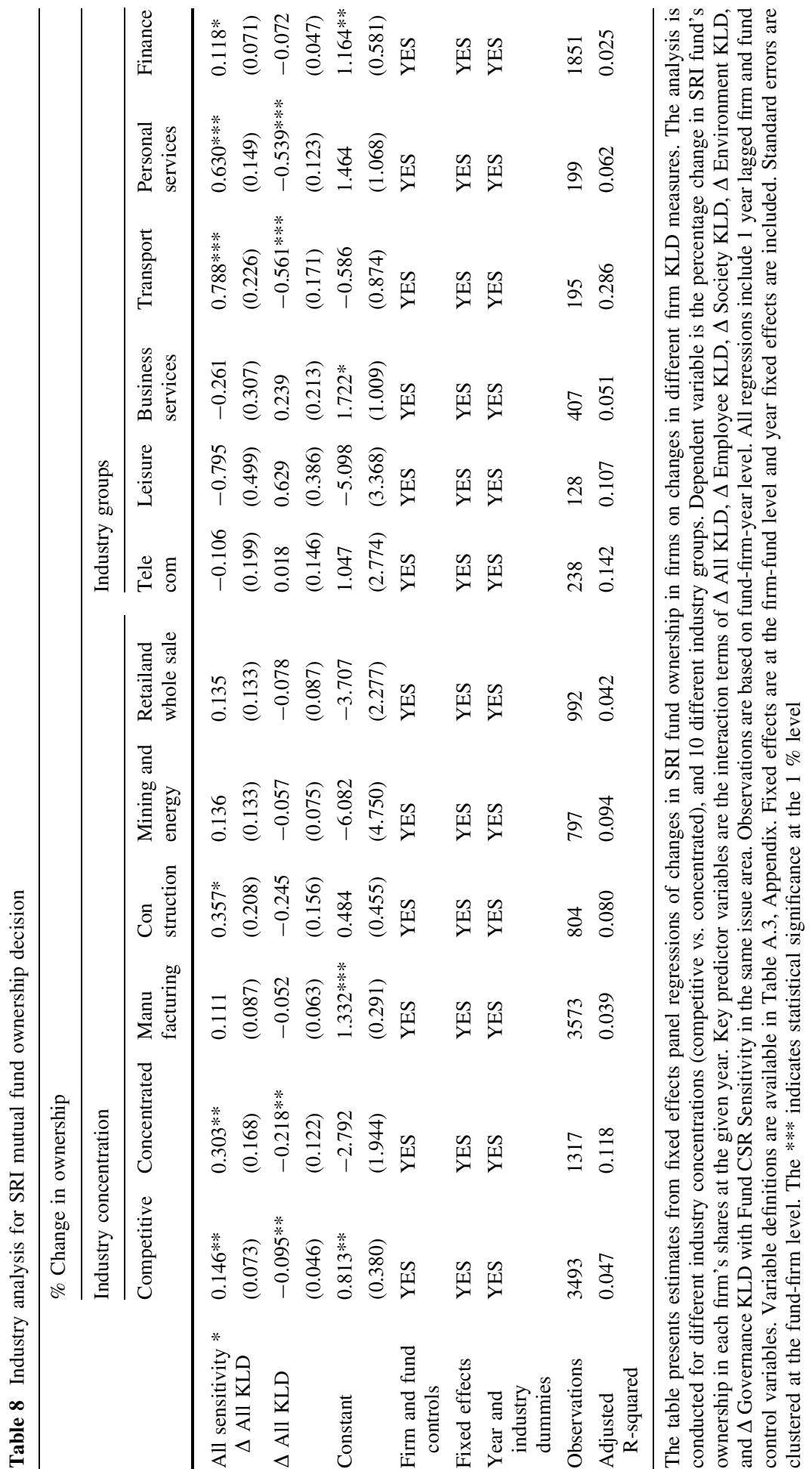


Table 9 Analyses for firm CSR increase after SRI ownership increase

\begin{tabular}{|c|c|c|c|c|}
\hline & $\begin{array}{l}\text { Increased SRI ownership } \\
(>0)\end{array}$ & $p$ value & $\begin{array}{l}\text { Big increase in SRI ownership (Top } \\
10 \% \text { ) }\end{array}$ & $p$ value \\
\hline \multicolumn{5}{|c|}{ Panel A: Increase in CSR score average after SRI ownership increase } \\
\hline$\Delta$ All KLD & 0.301 & 0.000 & 0.486 & 0.000 \\
\hline $\begin{array}{l}\Delta \text { Employee } \\
\text { KLD }\end{array}$ & 0.196 & 0.000 & 0.283 & 0.000 \\
\hline$\Delta$ Society KLD & 0.230 & 0.000 & 0.377 & 0.000 \\
\hline $\begin{array}{l}\Delta \text { Environment } \\
\text { KLD }\end{array}$ & 0.088 & 0.000 & 0.130 & 0.005 \\
\hline $\begin{array}{l}\Delta \text { Governance } \\
\text { KLD }\end{array}$ & 0.035 & 0.002 & 0.082 & 0.034 \\
\hline
\end{tabular}

Panel B: Increase in CSR score average after SRI fund ownership increase (Funds with CSR sensitivity in top quintile only)

\begin{tabular}{|c|c|c|c|c|}
\hline$\Delta$ All KLD & 0.309 & 0.000 & 0.680 & 0.000 \\
\hline $\begin{array}{l}\Delta \text { Employee } \\
\text { KLD }\end{array}$ & 0.214 & 0.000 & 0.312 & 0.000 \\
\hline$\Delta$ Society KLD & 0.240 & 0.000 & 0.425 & 0.000 \\
\hline $\begin{array}{l}\Delta \text { Environment } \\
\text { KLD }\end{array}$ & 0.089 & 0.000 & 0.160 & 0.003 \\
\hline $\begin{array}{l}\Delta \text { Governance } \\
\text { KLD }\end{array}$ & 0.037 & 0.005 & 0.090 & 0.041 \\
\hline
\end{tabular}

Panel C: Increase in CSR score average after SRI fund ownership increase (Funds with CSR sensitivity in bottom quintile only)

\begin{tabular}{|c|c|c|c|c|}
\hline$\Delta$ All KLD & 0.208 & 0.002 & 0.181 & 0.317 \\
\hline $\begin{array}{l}\Delta \text { Employee } \\
\text { KLD }\end{array}$ & 0.131 & 0.000 & 0.201 & 0.046 \\
\hline$\Delta$ Society KLD & 0.238 & 0.001 & 0.117 & 0.448 \\
\hline $\begin{array}{l}\Delta \text { Environment } \\
\text { KLD }\end{array}$ & 0.080 & 0.001 & 0.032 & 0.566 \\
\hline $\begin{array}{l}\Delta \text { Governance } \\
\text { KLD }\end{array}$ & 0.030 & 0.177 & 0.099 & 0.198 \\
\hline
\end{tabular}

The table presents the test results whether the increase in Firm CSR Score averages (from current to next year) is different from zero after SRI funds increase their ownership in those firms (from prior to current year). The analysis is conducted for any level of SRI ownership increase, as well as, only for big increases in top $10 \%$ category. Panel A gives the findings for all SRI mutual funds. In Panel B, I use SRI funds with very high CSR sensitivity (in top quintile), while in Panel C, the analysis includes only the funds with low CSR sensitivity (in bottom quintile). $P$ values for the differences are provided. Variable definitions are available in Table A.3, Appendix

investments; and compare them to the portfolio of firms in which SRI funds decreased their ownerships. In particular, I examine each fund's portfolio which includes the stock returns of the firms with increased (decreased) fund investment. The fund's portfolio return is the weighted average of those firms' stock returns; and each stock return in the portfolio is weighted by the fund's ownership percentage in that stock.

First, I consider the whole sample to conduct the fund performance analysis. Then, I repeat the test individually for each year in order to control for omitted time-variant factors. Table 11 provides the results. For the whole sample, the significant and negative estimates for "Invested" indicate that funds fail to improve the performance of their investment portfolios. Specifically, the return for the portfolio of invested firms is 
$-0.221 \%$ for the entire sample. Statistically significant findings for year-by-year analyses suggest SRI portfolio of firms with increased ownership has negative returns of -0.040 , $-0.236,-0.299$, and $-0.307 \%$ in $2003,2005,2009$, and 2010 , respectively. A comparison of these significant estimates to the returns of the mutual fund market and NASDAQ reveals that SRI portfolios of firms underperform both markets.

I further examine the SRI portfolio performance for the different Fund CSR Sensitivity levels. CSR Sensitivity plays an important role in SRI mutual funds' investments. Hence, it may have an impact on the funds' stock selection and subsequently, on the performance of their portfolios. One could expect SRI funds with high CSR sensitivity actively implement the CSR trading strategy. They might evaluate firms' CSR practices more accurately and build their portfolios accordingly. Therefore, they might have better performing portfolios of stocks compared to the SRI mutual funds with lower CSR sensitivity. I construct two sub-samples of high and low CSR Sensitivity. The high CSR sensitivity sample includes the funds in the top quintile of the sensitivity measure. I use the bottom quintile of the sensitivity measure to select funds and their portfolios for the low CSR sensitivity sample. Table 12 presents the findings. The estimates of "Invested" suggest that SRI mutual funds still fail to improve the performance of their portfolios for different CSR sensitivity groups. Particularly, the funds with low CSR sensitivity perform worse by $-0.454 \%$ whereas the portfolio return for the whole sample is $-0.221 \%$. For ethically more conscious SRI funds, the portfolio return is less negative but statistically not significant. Contrary to expectations, these findings imply that mutual funds with high CSR sensitivity are not successful to build portfolios with good performance, and the CSR trading strategy cannot improve the portfolio performance. Furthermore, funds have more negative return portfolios of firms when those funds are less sensitive towards CSR practices of firms in which they invest. One possible explanation may be their poor ability of selecting positive return CSR firms when those funds are not carefully involved in CSR as they are less sensitive towards these issues.

Table 10 Performance comparison between the market and SRI funds' investment portfolios

\begin{tabular}{|c|c|c|c|c|}
\hline Years & Invested portfolio & NASDAQ & Difference & $P$ value \\
\hline Whole sample & 0.079 & 0.175 & -0.096 & 0.000 \\
\hline 2003 & 0.371 & 0.940 & -0.569 & 0.000 \\
\hline 2004 & 0.104 & 0.208 & -0.104 & 0.000 \\
\hline 2005 & 0.020 & 0.015 & 0.005 & 0.719 \\
\hline 2006 & 0.069 & 0.155 & -0.086 & 0.002 \\
\hline 2007 & 0.008 & -0.078 & 0.086 & 0.002 \\
\hline 2008 & -0.383 & -0.476 & 0.093 & 0.006 \\
\hline 2009 & 0.265 & 0.678 & -0.413 & 0.000 \\
\hline 2010 & 0.143 & 0.266 & -0.123 & 0.000 \\
\hline 2011 & 0.003 & -0.132 & 0.135 & 0.019 \\
\hline 2012 & 0.127 & 0.170 & -0.043 & 0.093 \\
\hline
\end{tabular}

The table shows mean differences between the market return and SRI mutual funds' portfolio return. The analysis is conducted for the whole sample including all years between 2003 and 2012, as well as, individually for each year. NASDAQ is chosen to represent the market since SRI mutual funds are large companies and mostly traded in NASDAQ. "Invested Portfolio" includes only firms with increased SRI fund investment. $P$ values for the differences are provided 


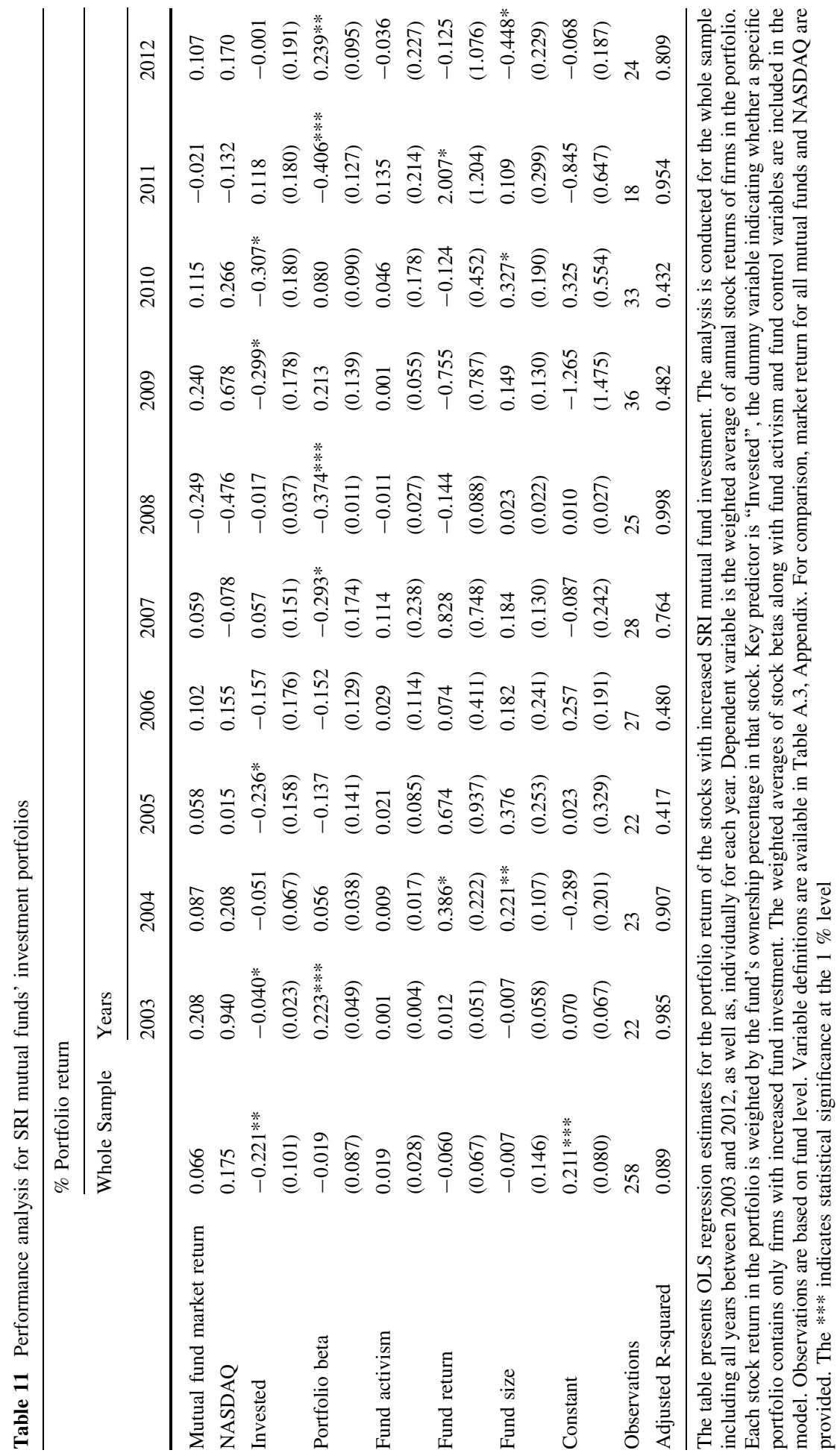


Table 12 SRI funds' performance analysis for different samples of CSR sensitivity

\begin{tabular}{|c|c|c|c|}
\hline & \multicolumn{3}{|c|}{$\%$ Portfolio return } \\
\hline & $\begin{array}{l}\text { Whole } \\
\text { sample } \\
\text { I }\end{array}$ & $\begin{array}{l}\text { Top quintile sample of fund CSR } \\
\text { sensitivity } \\
\text { II }\end{array}$ & $\begin{array}{l}\text { Bottom Quintile sample of fund CSR } \\
\text { sensitivity } \\
\text { III }\end{array}$ \\
\hline \multirow[t]{2}{*}{ Invested } & $-0.221 * *$ & -0.368 & $-0.454^{*}$ \\
\hline & $(0.101)$ & $(0.475)$ & $(0.253)$ \\
\hline \multirow[t]{2}{*}{ Portfolio beta } & -0.019 & 0.150 & -0.161 \\
\hline & $(0.087)$ & $(0.112)$ & $(0.157)$ \\
\hline \multirow[t]{2}{*}{ Fund activism } & 0.019 & 0.054 & -0.136 \\
\hline & $(0.028)$ & $(0.127)$ & $(0.117)$ \\
\hline \multirow[t]{2}{*}{ Fund return } & -0.060 & 0.261 & -0.175 \\
\hline & $(0.067)$ & $(0.211)$ & $(0.198)$ \\
\hline \multirow[t]{2}{*}{ Fund size } & -0.007 & -0.189 & 0.296 \\
\hline & $(0.146)$ & $(0.435)$ & $(0.325)$ \\
\hline \multirow[t]{2}{*}{ Constant } & $0.211 * * *$ & 0.022 & $0.601 * *$ \\
\hline & $(0.080)$ & $(0.252)$ & $(0.259)$ \\
\hline Observations & 258 & 24 & 59 \\
\hline $\begin{array}{l}\text { Adjusted } \\
\text { R-squared }\end{array}$ & 0.089 & 0.181 & 0.123 \\
\hline
\end{tabular}

The table presents OLS regression estimates for the portfolio return of the stocks with increased SRI mutual fund investment. The analysis is conducted for the whole sample, as well as, for the samples with high and low Fund CSR Sensitivity. The high CSR sensitivity sample includes the funds in the top quintile of the sensitivity measure and the portfolios of stocks invested by those funds only. The low CSR sensitivity sample has the funds in the bottom quintile of the sensitivity measure and the portfolios of stocks invested by those funds only. Dependent variable is the weighted average of annual stock returns of firms in the portfolio. Each stock return in the portfolio is weighted by the fund's ownership percentage in that stock. Key predictor is "Invested", the dummy variable indicating whether a specific portfolio contains only firms with increased fund investment. The weighted averages of stock betas along with fund activism and fund control variables are included in the model. Observations are based on fund level. Variable definitions are available in Table A.3, Appendix. The *** indicates statistical significance at the $1 \%$ level

\section{Conclusion}

In this paper, I examine SRI mutual funds' ownership in firms with CSR practices. I use a comprehensive measure that combines SRI funds' own CSR perception with the corporate CSR scores to explain funds' investment in these firms. Using changes in (in)dependent variables, lagged control variables and a different model with the new SRI fund emergence only, I control for the potential endogeneity issue in the analysis. I find strong evidence that SRI funds increase their ownership in the firms having higher CSR when those funds are sensitive to CSR policies. The results also hold for a larger sample of mutual funds, as well as, after controlling for different measures on liquidity. My findings indicate SRI mutual funds have distinctively higher ownership in firms when those firms improve Employee Relations and Society areas of CSR. While industry concentration does not have influence on the fund investment, SRI funds particularly choose socially responsible firms operating in construction, transportation, personal services, and financial sector. I provide evidence for CSR improvement in companies after socially conscious mutual funds increase their holdings in those firms. I show the funds with CSR sensitivity underperform the market in 
general and fail to improve their portfolio performance after they invest in the firms with high CSR.

This paper contributes the fund investment and CSR literature by suggesting an explanation for SRI fund ownership using a new instrument and a new measure which incorporates the fund CSR perspective in the investment decision. This study also provides insight into particular CSR practices attracting the fund investment; and hence, it may guide companies for determining their CSR policies. This paper demonstrates whether SRI portfolios can achieve high returns; and thus, it has the potential to help socially conscious funds with their future investment decisions.

Acknowledgments I am grateful to S. Katie Moon for her tremendous support in this paper. I appreciate helpful comments of seminar participants at University of Warwick. I thank Deanna Salcedo for valuable research assistance.

Open Access This article is distributed under the terms of the Creative Commons Attribution 4.0 International License (http://creativecommons.org/licenses/by/4.0/), which permits unrestricted use, distribution, and reproduction in any medium, provided you give appropriate credit to the original author(s) and the source, provide a link to the Creative Commons license, and indicate if changes were made.

\section{References}

Albuquerque R, Durnev A, Koskinen Y (2014) Corporate social responsibility and firm risk: theory and empirical evidence. Unpublished working paper

Amihud Y (2002) Illiquidity and stock returns: cross-section and time-series effects. J Financ Mark 5:31-56

Baron DP (2008) Managerial contracting and corporate social responsibility. J Public Econ 92:268-288

Bauer R, Koedijk K, Otten R (2005) International evidence on ethical mutual fund performance and investment style. J Bank Finan 29:1751-1767

Benabou R, Tirole J (2010) Individual and corporate social responsibility. Economica 77:1-19

Benson KL, Brailsford TJ, Humphrey JE (2006) Do socially responsible fund managers really invest differently? J Bus Ethics 65:337-357

Berry TC, Junkus JC (2013) Socially responsible investing: an investor perspective. J Bus Ethics 112:707-720

Buzby SL, Falk H (1978) A survey of the interest in social responsibility information by mutual funds. Acc Organ Soc 3:191-201

Cheng B, Ioannou I, Serafeim G (2014) Corporate social responsibility and access to finance. Strateg Manag J 35:1-23

Chung H, Lee HH, Tsai PC (2012) Are green fund investors really socially responsible? Rev Pac Basin Financ Mark Policies 15:1-25

Derwall J, Koedijk K (2009) Socially Responsible Fixed-Income Funds. J Bus Finance Account 36:210-229

Economist (2008) Just good business. Special report on CSR January, 19th

Edmands A (2012) The link between job satisfaction and firm value, with implications for corporate social responsibility. Acad Manag Perspect 26:1-19

Filbeck G, Gorman R, Zhao X (2013) Are the best of the best better than the rest? The effect of multiple rankings on company value. Rev Quant Financ Acc 41:695-722

Geczy C, Stambaugh FR, Levin D (2005) Investing in socially responsible mutual funds. Unpublished working paper

Ghoul SE, Guedhami O, Kwok CCY, Mishra DR (2011) Does corporate social responsibility affect the cost of capital? J Bank Finance 35:2388-2406

Gillan S, Hartzell JC, Koch A, Starks L (2010) Firms' environmental, social and governance (ESG) choices, performance and managerial motivation. Unpublished working paper

Giuli AD, Kostovetsky L (2014) Are red or blue companies more likely to go green? Politics and corporate social responsibility. J Financ Econ 111:158-180

Goldreyer EF, Diltz JD (1999) The performance of socially responsible mutual funds: incorporating sociopolitical information in portfolio selection. Managerial Finance 25:23-36

Hoberg G, Phillips G (2010) Product market synergies and competition in mergers and acquisitions: a textbased analysis. Rev Financ Stud 23:3773-3811 
Hong H, Kostovetsky L (2012) Red and blue investing: values and finance. J Financ Econ 103:1-19

Karakas O, Dimson E, Li X (2015) Active ownership. Rev Financ Stud 28:3225-3268

Lesmond DA, Ogden JP, Trzcinka CA (1999) A new estimate of transaction costs. Rev Financ Stud 12:1113-1141

Mallin CA, Saadouni B, Briston RJ (1995) The financial performance of ethical investment funds. J Bus Finance Account 22:483-496

Moon SK, Tosun OK (2016) What makes social responsibility financially valuable? Unpublished working paper

Nelling E, Webb E (2009) Corporate social responsibility and financial performance: the 'virtuous circle' revisited. Rev Quant Financ Acc 32:197-209

Portne PR (2008) The (Not So) new corporate social responsibility: an empirical perspective. Rev Environ Econ Policy 2:261-275

Rahman S, Lee C, Xiao Y (2016) The investment performance, attributes, and investment behavior of ethical equity mutual funds in the US: an empirical investigation. Rev Quant Financ Acc. doi:10.1007/ s11156-016-0581-1

Renneboog L, Horst JT, Zhang C (2008) Socially responsible investments: institutional aspects, performance, and investor behavior. J Bank Finance 32:1723-1742

Schroder M (2007) Is there a difference? The performance characteristics of SRI equity indices. J Bus Finance Account 34:331-348

Sparkes R, Cowton CJ (2004) The maturing of socially responsible investment: a review of the developing link with corporate social responsibility. J Bus Ethics 52:45-57

Statman M (2000) Socially responsible mutual funds. Financ Analysts J 56:30-39

US Social Investment Forum Foundation (2014) Report on US Sustainable, Responsible and Impact Investing Trends 2014. The Forum for Sustainable and Responsible Investment 10th edn. http://www. ussif.org/files/publications/sif_trends_14.f.es.pdf. Accessed 10 January 2015

Williams G (2007) Some determinants of the socially responsible investment decision: a cross-country study. J Behav Finance Account 8:43-57

Wu MW, Shen CH, Cheng TH (2016) Application of multi-level matching between financial performance and corporate social responsibility in the banking industry. Rev Quant Financ Acc. doi:10.1007/ s11156-016-0582-0

Yu L (2014) Performance of socially responsible mutual funds. Global J Bus Res 8:9-17 